\title{
Turist Rehberliği Alanındaki Lisansüstü Tezlerin Bibliyometrik Analiz ile Değerlendirilmesi (1989-2019)
}

\section{Review of Postgraduate Theses about Tourist Guide Field with Bibliometric Analysis \\ (1989-2019)}

Arș. Gör. Nazlı ÖRNEK

Erciyes Üniversitesi, Turizm Fakültesi, Türkiye Erciyes University, Faculty of Tourism, Turkey

E-Mail: nazliornek@erciyes.edu.tr

Prof. Dr. Kurtuluş KARAMUSTAFA

Erciyes Üniversitesi, Turizm Fakültesi, Kayseri Üniversitesi, Rektörlük, Türkiye Erciyes University, Faculty of Tourism, Kayseri University, Rector's Office, Turkey

E-Mail: karamustafa@erciyes.edu.tr

\section{$\ddot{O} z$}

Amaç ve Önem: Bu çalışma, 1989-2019 yılları arasında Yükseköğretim Kurulu Ulusal Tez Merkezi (YÖKTEZ) veri tabanında yayınlanan turist rehberliği alanı ile ilgili hazırlanmış, erişime açık lisansüstü tezlerin gelişim sürecini değerlendirerek ilgili alanda ileride yapılacak çalışmalara birikimsel katkı oluşturmayı amaçlamaktadır. Bu bağlamda çalışmanın önemi, konu ile ilgili ileri düzeyde yapılacak çalışmalara bütünsel boyutta yol gösterici nitelikte bilgiler sunulmasına dayanmaktadır.

Yöntem: YÖKTEZ veri tabanında yer alan turist rehberliği alanı ile ilgili yayınlanmış ve erişime açık 18 adet doktora tezi ile 105 adet yüksek lisans tezi bibliyometrik değerlendirmeye tabi tutulmuştur. Bibliyometrik değerlendirmeler, sosyal bilimler için geliştirilmiş istatistik programı ile sıklık ve yüzde değerleri hesaplanarak gerçekleştirilmektedir.

Bulgular: Her iki tez türünün de daha çok saha araştırmasına dayalı (ampirik) olduğu ve araştırmalarda nicel yöntemlerin sıklıkla kullanıldığı, konu olarak ise turist rehberlerinin rolleri, fonksiyonları, mesleki yeterlilikleri, mesleki sorunları ve turist rehberliği eğitiminin üzerine yoğunlaşıldığı anlaşılmaktadır.

Özgünlük/Bilimsel Katkı: Çalışmada, kendine özgü yaklaşım ve parametreler kapsamında ileri düzeyde yapılacak çalışmalara bütünsel bir bakış ile yol gösterici nitelikte bilgiler sunulmaktadır.

Anahtar Kelimeler: Turist rehberliği, lisansüstü eğitim, tez, bibliyometrik analiz.

Makale Türü: Araştırma makalesi

\begin{abstract}
Purpose and Importance: This study has been prepared by examining the development process of postgraduate theses prepared in the tourist guide field and available in the database of the Council of Higher Education Thesis Center between the years of 1989 and 2019 in order to make contribution to the relevant body of knowledge accumulation. In this context, the importance of the study is to provide additional holistic information for further studies.
\end{abstract}

Methodology: 18 doctoral theses and 105 master's theses on the field of tourist guide accessible in the Council of Higher Education Thesis Center database have been evaluated via bibliometrics based on selected parameters. The analysis of the obtained data has been carried out by calculating the frequency and percentage values within statistics program developed for the social sciences.

Atıf için (for cited); Örnek N. ve Karamustafa, K. (2020). Turist Rehberliği Alanındaki Lisansüstü Tezlerin Bibliyometrik Analiz ile Değerlendirilmesi (1989-2019), Turist Rehberliği Dergisi, 3(2), 115-138. 


\section{IIIIII $\odot$}

Turist Rehberliği Dergisi (TURED) \& Y11. 2020, Cilt. 3, Sayı. 2

Journal of Tour Guiding (JOTOG) \& Year. 2020, Volume. 3, Issue. 2

Findings: It can be stated that both thesis types are mostly based on field research (empirical) and quantitative methods. The studies investigated focus mainly on issues such as tourist guides' roles, functions, professional competencies, and professional problems education issues.

Originality/Value: This study presents holistic and specific information to the further studies with its unique approach and parameters.

Keywords: Tourist guidance, postgraduate education, dissertation, thesis, bibliometric analysis.

Paper Type: Research article

\section{Giriş}

Turist rehberliği mesleği, turizm hizmetlerinin nitelikli bir şekilde sunulabilmesi için olmazsa olmaz meslek grupları arasında değerlendirilmektedir; çünkü turist rehberliği mesleği, sadece turistlere kılavuzluk yapma görevinin yerine getirmemekte, aynı zamanda ziyarette bulunulan bölge veya ülkeyi temsil etmek, kültürel değerleri tanıtmak, imaj ve markalaşma konusunda katkılar oluşturmak ve bütün bunların neticesinde de bir taraftan başta döviz kazandırarak ekonomik fayda oluşturmak, diğer taraftan da kültürel unsurları tanıtmak gibi önemli bir sosyal fonksiyonun da yerine getirilmesine katkı sağlamaktadır (Cohen, 1985; Ap and Wong, 2001; Dahles, 2002). Grönroos (1978: 598), özellikle yabancı turlardan söz ederken turistlerin, masa başı acenta çalışanlarını sadece turu satın alırken gördüklerini, hatta bazen hiç görmediklerini, sürekli olarak turist rehberi ile etkileşim içinde olmalarından dolayı turist rehberlerini "bir sonraki turu satan kişî" olarak da tanımlamaktadır. $\mathrm{Bu}$ bağlamda, turist rehberlerinin, müşteri memnuniyeti ve sadakatinin oluşturulması gibi önemli pazarlama fonksiyonunu da icra ettiklerini ifade etmek gerekir (Nguyen, 2015: 2). Buradan anlaşılacağı üzere, destinasyonların turistler tarafindan etkin bir şekilde ziyaret edilebilmesi, bu ziyaretler esnasında turistlerin doğru ve detaylı bir şekilde bilgilendirilmesi ve nihayetinde de nitelikli bir turizm faaliyetinin ortaya konulabilmesi için turist rehberleri son derece önemli bir role sahiptirler. Ancak turizm ile doğrudan alakalı mesleklere yönelik, özellikle İkinci Dünya Savaşı sonrasında, hızla gelişen ve artan çok farklı düzeylerde eğitim, öğretim ve araştırma faaliyetlerinin bulunmasına rağmen (Conner and Bohan, 2014: 93) Yükseköğretim Program Atlas1 incelendiğinde, Türkiye'de doğrudan turist rehberliği mesleği alanına ilişkin farklı düzeylerde eğitim, öğretim ve araştırma faaliyetlerinin oldukça yeni olduğu ifade edilmelidir.

Turizm ve ağırlama alanında yapılan akademik çalıșmaların olgunluk düzeyinin belirlenmesinde hem niceliksel (temel veya ileri tekniklerle bibliyometrik analiz gibi) hem de niteliksel (literatür taraması gibi) tekniklerle gerçekleştirilen araştırmaların gerekli olduğu ifade edilmektedir (Koseoglu, Sehitoglu \& Craft 2015: 359). Bu bağlamda turist rehberliği ile ilgili yapılan çalışmaların geçmişe dönük bir incelemesinin yapılması, belirlenen parametreler 1şı̆̆ında bu çalışmaların analiz edilmesi hem turist rehberliği mesleğini icra edenlere hem de konu ile ilgili çalışma yapacak olan araştırmacılara bütünsel olarak yol gösterici fikirler sunması açısından önemli olarak değerlendirilmektedir. Diğer bir ifade ile akademik çalışmaların bilimsel olarak gelişim sürecinin ortaya konulmasında bibliyometriden yararlanılmaktadır. Bu bağlamda bu çalışma ile Türkiye'de turist rehberliği alanında yapılmış lisansüstü tezler geçmişten günümüze yılı, türü, üniversitesi, enstitüsü, ana bilim dalı, danışman unvanı, örneklem alanı, araştırma türü, araştırma deseni, örneklem sayısı, uygulama kitlesi, veri toplama arac1, Türkçe ve yabancı kaynak sayısı, toplam sayfa sayıs1, konusu ve anahtar kelimelerinde en sık tekrar eden kelimeler gibi birtakım parametreler dikkate alınarak bibliyometrik değerlendirmeye tabi tutulmuş, bu alandaki bilgi birikimine katkılar oluşturulmaya ve akademik çevrelerce ilgili alanda ileride yapılabilecek çalışmalara 1şık tutmaya çalışılmıştır. 
Turist Rehberliği Dergisi (TURED) \& Y1l. 2020, Cilt. 3, Say1. 2

Journal of Tour Guiding (JOTOG) \& Year. 2020, Volume. 3, Issue. 2

\section{Kavramsal Çerçeve}

Lisansüstü eğitim, lisans derecesini tamamlamış olan öğrencilerin ilgi gösterdiği bilim dalında yüksek lisans veya doktora öğrenimi yaparak öğrenciye uzmanlaşma imkânı veren, üst düzey eğitim programıdır (Beşel, 2017: 28). 2547 sayılı Yükseköğretim Kanunu'na (1981) göre yüksek lisans, "bir lisans öğretimine dayalı, eğitim-öğretim ve araştırmanın sonuçlarını ortaya koymayı amaçlayan bir yüksekögretim olarak, doktora ise lisansa dayalı en az altı veya yüksek lisans veya eczacıllk veya fen fakültesi mezunlarınca Sağllk ve Sosyal Yardım Bakanlı̆̆ tarafindan düzenlenen esaslara göre bir laboratuvar dalında kazanılan uzmanlı̆̆a dayalı en az dört yarıylllı programı kapsayan ve orijinal bir araştırmanın sonuçlarını ortaya koymayı amaçlayan bir yükseköğretim" olarak tanımlanmaktadır. Günümüzde üniversitelere öğretim elemanı yetiştirmenin dışında, endüstriyel alanlarda ve diğer çalışma alanlarında iş edinmenin bir ön koşulu olarak yüksek lisans ve doktora derecesinin de aranması, lisansüstü eğitime olan ihtiyacı daha da artırmıştır (Karaman \& Bakırc1, 2010: 95). Gerek akademide gerek uygulama alanında kişinin bir alanda uzmanlaşması, o alanla ilgili geniş bir bakışa sahip olabilmesi ve bunu kullanabilmesi o kişiyi çalıştığ 1 alanda ön plana çıkaran bir ayrıcalık olarak görülmektedir. Bu kapsamda bir ülkede, bilim insanı yetiştirme ve ulusal bilim politikasının yürütülmesinde bilgiyi üretme, kullanma ve eleştirme düşünce tarzıyla yaklaşan lisansüstü eğitim (Karaman \& Bakırc1, 2010) ülkelerin eğitim düzeyinin gelişimini göstermesi açısından en önemli parametrelerden biri olarak ifade edilebilir.

Bir disiplinin gösterdiği gelişimin incelenmesinde ilgili alanda hazırlanan lisansüstü tezler büyük oranda yol gösterici nitelikte olmaktadır (Tayfun vd., 2016: 55; Küçükoğlu \& Ozan 2013: 28). $\mathrm{Bu}$ anlamda turist rehberliği alanı ile ilgili tezlerin ortaya çıkarılmasına ortam hazırlayan üniversitelerin ve lisansüstü programlarının önemi yadsınamaz. Bir alanla ilgili lisansüstü tezlerin ve programların bulunması ve artması, o alan hakkında yapılan proje, makale, bildiri gibi akademik çalışmaların da zenginliği ve çeşitliliği açısından önem arz etmektedir. Bunun yanı sıra ülkelerde, her bir alan için gerçekleştirilen araştırma sayısının artması, o ülkelerin bilimsel tanınırlı̆̆ına da katkı sağlayacağı düşünüldügünde, bilimsel çalışmaların önemini daha da ön plana çıkarmaktadır (Tayfun vd., 2018: 524). Her iki anlamda da lisansüstü çalışmaların yol açıcı bir fonksiyona sahip olduğu ifade edilmektedir. Bu anlamda doğrudan lisansüstü çalışmaların gelişimini dolaylı olarak da ilgili alanla ilgili yapılan diğer akademik çalışmaları incelenmek ve o disipline ait gelişim seyrini göstermek amacıyla bibliyometrik analizlerin kullanıldığı bazı araştırmalar (Armutlu \& Arı, 2010; Alkan, 2014; Aydın, 2017; Alımanoğlu \& Ayazlar, 2017; Beşel, 2017; Demirbulat \& Dinç, 2017; Gökkaya vd., 2017; İnceoğlu, 2014; Sünnetçioğlu vd., 2017; Tayfun vd., 2016; Tayfun vd., 2018) bulunmaktadır. Bu araştırmalara ait detaylı bilgiler Tablo 1'de gösterilmektedir.

Turizm alanında bu çalışmaların araştırma kalitesinin, etki ve prestij faktörlerine olan ilginin ve gelişiminin bibliyometrik analiz ile araştırılması da önemlidir (Hall, 2011: 16). Bu doğrultuda turizm alanında yapılan bibliyometrik çalışmalar incelendiğinde turizmin alt boyutlarına ve ilgili bulunduğu farklı konulara ilişkin olarak turizm pazarlaması (Özel \& Kozak, 2012), turizm dergilerinde yayınlanan inovasyon ile ilgili makaleler (Ülker, Örnek \& Çalhan, 2019), turizm eğitimi (Üzümcü, 2019), kırsal turizm (Bozok, Kılıç \& Özdemir, 2017), sürdürülebilir turizm (Demirbulat \& Dinç, 2017), sağlık turizmi (Temizkan, Çiçek \& Özdemir, 2015) gibi çalıșmalara ve ayrıca ilgili konu ile alakalı olarak turist rehberliği alanı ile ilgili yapılan akademik çalışmaların bibliyometrik analizini konu alan çalışmalar (Şahin \& Acun, 2015a; Şahin \& Acun, 2015b; Çapar, Toksöz \& Dönmez, 2018; Özsoy \& Çokal, 2018; Kaygalak \& Kırlar, 2019, Arıkan Saltık, 2020; Zengin \& Atasoy, 2020) ile literatüre katkı sağlanmıştır (bkz. Tablo 2). Buna karşın ilgili alanın lisansüstü tezlerini ele alarak yapılan sınırlı sayıda ve sınırlı parametreler özelinde çalışmaların yapıldığı görülmektedir. Ayrıca lisansüstü tezleri ele alan çalışmalarda farklı türdeki çalışmaların (makale, uluslararası bildiri) da araştırmaya dâhil edilmesinden kaynaklı olarak araştırmalarda kullanılan parametrelerin sınırlı tutulduğu ifade edilebilir. Bu çalışmalardan biri Çapar vd. (2018) tarafından hazırlanan 2005-2017 yılları arasında ulusal ve uluslararası hazırlanmış tezleri inceleyen çalışmadır.

Örnek ve Karamustafa; Turist Rehberliği Alanındaki Lisansüstü Tezlerin Bibliyometrik Analiz ile Değerlendirilmesi / Review of Postgraduate Theses about Tourist Guide Field with Bibliometric Analysis (1989-2019) 
Turist Rehberliği Dergisi (TURED) \& Yıl. 2020, Cilt. 3, Sayı. 2

Journal of Tour Guiding (JOTOG) \& Year. 2020, Volume. 3, Issue. 2

Gerek ulusal tezlerin yayın yıllarının 2005 yılı itibari ile başlatılması, gerekse uluslararası tezler ve makalelerin de çalışmaya dâhil edilmesinden kaynaklı daha sınırlı sayıda parametreye yer verilmiş olduğu ifade edilebilir. Benzer şekilde Şahin ve Acun (2015a) da çalışmalarında lisansüstü tezlerin yanında makalelere de yer vermelerinden kaynaklı olarak incelenen parametreleri daha sinırlı tutmuşlardır. Bu çalışmaların artması ileride yapılacak çalışmalara bütünsel olarak yol gösterici nitelikte olacaktır.

Turist rehberliği çalışmalarında çoğunlukla ele alınan parametreler tez türü, yayın yılı, hazırlandığı üniversite, bağlı bulunduğu enstitü, danışman unvanı gibi özelliklerdir. Çalışmalarda lisansüstü tezlerin türlerine göre sinıflandırılarak analiz edilmesine, örneklem alanlarına, örneklem büyüklüklerine, kaynak dağılımlarına, tezlerin sayfa sayılarının ortalamalarına dair bir bulguya rastlanmamıştır. Buradan hareketle bu çalışmada, bibliyometrik analizin sunmuş olduğu birden fazla parametre kullanım olanağı ışığında, bu çalışmanın farklı parametreler dikkate alınarak yapılması, sadece lisansüstü tezlerin incelenmesine yönelik olarak gerçekleştirilmesi ve güncel veriyi de örneklemine dâhil etmesi yönünden diğer çalışmalardan ayırılmaktadır. Bu bağlamda bu çalışma, konu ile ilgili ileri düzeyde yapılacak çalışmalara bütünsel boyutta yol gösterici nitelikte bilgiler sunulmasına dayanmaktadır. Araştırmanın ortaya konulma motivasyonunu ise bir alanın gösterdiği gelişimin incelenmesi aşamasında, o alanla ilgili hazırlanan lisansüstü tezlerin bulunmasi; ilgili alan hakkında hazırlanan makale, bildiri gibi akademik çalışmaların zenginliği ve çeşitliliğine doğrudan veya dolaylı olarak zemin hazırlamasına ve bilgi birikimine katkı sağlayacağı varsayımı oluşturmaktadır.

Tablo 1. Lisanüstü Tezleri İnceleyen Bibliyometrik Çalışmaların Bazıları

\begin{tabular}{|c|c|c|}
\hline Yazarlar & Konu & Kullanılan Parametreler \\
\hline $\begin{array}{l}\text { Armutlu \& Ar1 } \\
\text { (2010) }\end{array}$ & $\begin{array}{l}\text { Yönetim modalarının } \\
\text { yüksek lisans ve doktora } \\
\text { tezlerine yansımaları: } \\
\text { Bibliyometrik bir analiz }\end{array}$ & $\begin{array}{l}\text { 1986-2008 yılları arasında yazılan } 520 \text { tez, farklı alanlarda yazılan tezlerin } \\
\text { y1llara göre dağılımı, işlenen konuların yıllara göre dağılımı, yıllara göre } \\
\text { incelenen tezlerde belirlenen yönetim modalarının dağılımı gibi farklı } \\
\text { özellikler açısından değerlendirilmiştir. }\end{array}$ \\
\hline Alkan (2014) & $\begin{array}{l}\text { Türkiye'de muhasebe } \\
\text { alanında yapılan } \\
\text { lisansüstü tez çalışmaları } \\
\text { üzerine bir araştırma }\end{array}$ & $\begin{array}{l}\text { 1984-2012 yılları arasında muhasebe alanında yazılan } 656 \text { lisansüstü tez, } \\
\text { içerik analizi yöntemi kullanılarak, konularına, kullanılan yönteme, } \\
\text { geliştirilen öneri ve alana katkı gibi belirli kriterlere göre incelenerek } \\
\text { sınıflandırılmıştır. }\end{array}$ \\
\hline Aydın (2017) & $\begin{array}{l}\text { Yiyecek içecek } \\
\text { işletmeciliği alanında } \\
\text { kayıtlı bulunan tezlerin } \\
\text { bibliyometrik analizi }\end{array}$ & $\begin{array}{l}\text { 1988-2013 yılları arasında yiyecek içecek işletmeciliği ile ilgili hazırlanan } \\
179 \text { tez en çok tercih edilen konular, araştırma türü, araştırma yaklaşımı, } \\
\text { araştırma alanı, araştırma yürütülen anabilim dalları, üniversiteler, } \\
\text { araştırmaya danışmanlık yapan kişiler şeklinde bulgulardan oluşmaktadır. }\end{array}$ \\
\hline $\begin{array}{l}\text { Alımanoğlu } \\
\text { \&Ayazlar } \\
(2017)\end{array}$ & $\begin{array}{l}\text { Türkiye'de kırsal turizm } \\
\text { konulu lisansüstü tez } \\
\text { çalışmaları üzerine } \\
\text { bibliyometrik bir } \\
\text { inceleme }\end{array}$ & $\begin{array}{l}\text { 2003-2016 yılları arasında kırsal turizm ile ilgili yayınlanan } 20 \text { tez, araştırma } \\
\text { tasarımı, özet kurgusu, lisansüstü düzey, danışman unvanı, araştırma yı1ı, } \\
\text { sayfa sayısı, araştırmanın yapıldığı bölge, örneklem sayısı, üniversite, enstitü } \\
\text { türü ve kırsal turizmle ilişkilendirilen konular gibi farklı parametrelere göre } \\
\text { ele alınmıştır. }\end{array}$ \\
\hline Beşel (2017) & $\begin{array}{l}\text { Türkiye'de maliye } \\
\text { alanında yapılmış } \\
\text { lisansüstü tezlerin } \\
\text { bibliyometrik analizi }\end{array}$ & $\begin{array}{l}\text { 2003-2017 yılları arasında maliye alanında yayınlanan } 1714 \text { lisansüstü tez, } \\
\text { tezlerin türü, yıllara göre dağılımı, yapıldıkları üniversiteler, tez yazarlarının } \\
\text { cinsiyet dağılımı, tez yazarlarının lisans mezuniyet dağılımı, danışman } \\
\text { dağılımı, danışman unvanı dağılımı, jüri dağılımı, izin durumu dağılımı, ana } \\
\text { bilim dalı dağılımı, bilim dalı dağılımı, bölüm sayısı dağılımı, sayfa sayıs1 } \\
\text { ortalamaları, en az ve en çok sayfa sayısı, sayfa aralığ1 dağılımı, anahtar } \\
\text { kelime dağılımı, başlık ve özetlerde en sık kullanılan kelimeler, içerik ve } \\
\text { yöntemlerine dair dağılım şeklinde tez türlerine göre karşılaştırılarak analiz } \\
\text { edilmiştir. }\end{array}$ \\
\hline $\begin{array}{l}\text { Demirbulat \& } \\
\text { Dinç (2017) }\end{array}$ & $\begin{array}{l}\text { Sürdürülebilir turizm } \\
\text { konulu lisansüstü tezlerin } \\
\text { bibliyometrik profili }\end{array}$ & $\begin{array}{l}\text { 1987-2015 yılları arasında hazırlanan sürdürülebilir turizm konulu tez } \\
\text { çalışmalarının bibliyometrik özelliklerinin incelenmesi için tez künyelerinde } \\
\text { yer alan tez türü, yayınlandığ } 1 \text { yıl, yayınlandığ üniversite, yayınlandığ1 } \\
\text { enstitü, yayınlandığı ana bilim dalı ve tezin çalışma konusu şeklinde } \\
\text { parametreler belirlenerek } 62 \text { lisansüstü tez bu parametrelere dayalı olarak } \\
\text { değerlendirilmiştir. }\end{array}$ \\
\hline
\end{tabular}


Turist Rehberliği Dergisi (TURED) \& Y1l. 2020, Cilt. 3, Sayı. 2

Journal of Tour Guiding (JOTOG) \& Year. 2020, Volume. 3, Issue. 2

Tablo 1. Lisanüstü Tezleri İnceleyen Bibliyometrik Çalışmaların Bazıları (Devamı)

\begin{tabular}{|c|c|c|}
\hline Yazarlar & Konu & Kullanılan Parametreler \\
\hline $\begin{array}{c}\text { Gökkaya vd., } \\
\text { (2017) }\end{array}$ & $\begin{array}{l}\text { Lun } \\
\text { Ki } \\
\text { li }\end{array}$ & $\begin{array}{l}\text { 00-2017 yılları arasında yazılan lisansüstü tezler, yayınlandığı yıl, tür, } \\
\text { iversite, enstitü, ana bilim dalı, konu ve veri toplama yöntemi açısından } \\
\text { celenmiştir. }\end{array}$ \\
\hline İnceoğlu (2014) & $\begin{array}{l}\text { Türkiye'de sinemayı } \\
\text { konu alan doktora tezleri } \\
\text { üzerine bibliyometrik bir } \\
\text { çözümleme }\end{array}$ & $\begin{array}{l}\text { 1985-2013 yılları arasında sinemayı konu alan } 1714 \text { doktora tezi yıllara, } \\
\text { tezlerde ele alınan yapım türlerine, yapım türlerinin yıllarına, temel } \\
\text { araştırma alanlarına, araştırılan ülke sinemalarına, yıllara göre Türk ve } \\
\text { dünya sineması üzerine yazılan doktora tezlerine, ana bilim/anasanat } \\
\text { dallarına, alan içi ve alan dışı tez sayılarına, yöntemlerine göre ele } \\
\text { alınmıştır. }\end{array}$ \\
\hline $\begin{array}{r}\text { Güçlü } N \\
(201\end{array}$ & fili & $\begin{array}{l}3 \text { yılları arasında turizm alanında hazırlanan } 1565 \text { yüksek lisans ve } \\
\text { ra tezleri tür, dil, yıl, üniversite, enstitü, anabilim dalı ve konu gibi } \\
\text { trik özellikleri açısından incelenmiştir. }\end{array}$ \\
\hline $\begin{array}{l}\text { Sünn } \\
\text { vd., }\end{array}$ & $\begin{array}{l}\text { da yazılmış } \\
\text { niye ilişkin } \\
\text { ometrik }\end{array}$ & $\begin{array}{l}\text { 1987-2017 yılları arasında hazırlanan gastronomi ile ilgili } 33 \text { tez yıl, tez } \\
\text { türü, üniversite, kullanılan diğer anahtar kelimeler, sayfa sayısı, danı̧̧man } \\
\text { akademik unvanı, tez konusu, benimsenen araştırma yaklaşımı, örnekleme } \\
\text { tekniği, örnekleme grubu, veri toplama aracı gibi değişkenler ele alınarak } \\
\text { bibliyografik açıdan incelenmiştir. }\end{array}$ \\
\hline $\begin{array}{l}\text { Tayfun vd., } \\
\text { (2016) }\end{array}$ & $\begin{array}{l}\text { anında yazılan } \\
\text { tezlere yönelik } \\
\text { trik bir analiz }\end{array}$ & $\begin{array}{l}\text { 1985-2016 yılları arasında hazırlanan turizm konulu } 367 \text { tez, bibliyografik } \\
\text { araştırma yöntemleri doğrultusunda belirli kriterlere göre sınıflandırılarak } \\
\text { özet kurgusu, yararlanılan disiplin, lisansüstü düzey, enstitü türü, danışman } \\
\text { unvanı ve araştırma yılı esas alınarak değerlendirilmeye tabi tutulmuştur. }\end{array}$ \\
\hline $\begin{array}{l}\text { Tayfun vd., } \\
\text { (2018) }\end{array}$ & $\begin{array}{l}\text { Turizm alanında yiyecek } \\
\text { ve içecek ile ilgili } \\
\text { lisansüstü tezlerin } \\
\text { bibliyometrik analizi }\end{array}$ & $\begin{array}{l}\text { 1990-2018 yılları arasında turizm ile ilgili altı ana bilim dalında yazılan } \\
\text { yiyecek ve içecek ile ilişkili } 164 \text { lisansüstü tez, tez ile ilgili özellikler, tez } \\
\text { yazarı ve danışmanına ilişkin özellikler, kullanılan kaynaklar gibi } \\
\text { parametreler çerçevesinde ele alınmıştır. }\end{array}$ \\
\hline
\end{tabular}

Tablo 2. Ulusal Alanyazında Turist Rehberliği Alanı ile İlgili Hazırlanan Bibliyometrik Çalışmalar ve Bulgular1

\begin{tabular}{|c|c|c|}
\hline Yazarlar & Konu & Bulgular \\
\hline $\begin{array}{l}\text { Şahin \& Acun } \\
\quad(2015 a)\end{array}$ & $\begin{array}{l}\text { Turist rehberliği } \\
\text { alanının bibliyometrik } \\
\text { profili (makaleler ve } \\
\text { lisansüstü tezler) }\end{array}$ & $\begin{array}{l}2015 \text { yılında turist rehberliği alanı üzerine yapmış oldukları bibliyometrik } \\
\text { çalışmalarında makale ve lisansüstü tezleri ele almış ve tezlerin daha çok } \\
\text { Balıkesir Üniversitesi bünyesinde ele alındığı ve Sosyal Bilimler Enstitüsü'ne } \\
\text { bağlı oldukları, araştırma yaklaşımının daha çok uygulamaya dönük ve nicel } \\
\text { olarak yapıldığı ve örneklem olarak seçilen grubun sıklıkla profesyonel turist } \\
\text { rehberleri olduğu sonucuna ulaşmışlardır. }\end{array}$ \\
\hline $\begin{array}{l}\text { Şahin \&Acun } \\
\text { (2015b) }\end{array}$ & $\begin{array}{l}\text { rist rehberliği } \\
\text { nının bibliyometrik } \\
\text { fili (ulusal turizm } \\
\text { gre bildirileri) }\end{array}$ & $\begin{array}{l}\text { En fazla bildirinin } 2009 \text { yılında yapılan } 10 \text {. UTK'da sunulduğu, bildirilerin } \\
\text { çoğunun iki yazarlı olarak hazırlandığı ve yazarların akademik unvanlarının } \\
\text { daha çok doktor öğretim üyesi olduğu, konu olarak ise daha çok turist } \\
\text { rehberliği eğitiminin ele alındığını ortaya koymuşlardır. }\end{array}$ \\
\hline $\begin{array}{l}\text { Çapar, Toksöz } \\
\text { \&Dönmez } \\
\text { (2018) }\end{array}$ & $\begin{array}{l}\text { Turizm rehberliği } \\
\text { alanında yapılan } \\
\text { akademik çalışmaların } \\
\text { incelenmesi }\end{array}$ & $\begin{array}{l}\text { 2005-2017 yılları arasında; YÖK Ulusal Tez Merkezi'nde ve Proquest } \\
\text { veritabanında erişilen tezler, ULAKBİ ve Google Akademik veri } \\
\text { tabanlarındaki erişilen ulusal makaleler ve Scimago Journal \& Country } \\
\text { Rank'de (SJR) üst sıralarda yer alan } 35 \text { turizm dergisinde yayınlanan } \\
\text { uluslararası makaleler, Lisansüstü Turizm Öğrencileri Araştırma } \\
\text { Kongreleri'nde sunulan bildirileri ele alarak yapmış oldukları araştırmalarında, } \\
\text { turizm rehberliği alanında toplamda } 91 \text { tezin yazıldığı, 2005-2017 yılları } \\
\text { arasında yayınlanan dergiler arasında yapılan kıyaslamalar sonucunda ulusal } \\
\text { makalelerin en fazla Balıkesir Üniversitesi SBE dergisinde yayınlandığı fakat } \\
\text { bununla birlikte } 2018 \text { yılı Haziran ayında ilk sayısını çıaran Turist Rehberliği } \\
\text { Dergisi'nde ise yayınlanan } 5 \text { makalenin olduğu, Uluslararası makaleler en fazla } \\
2013 \text { yılında ve Asia Pacific Journal of Tourism dergisinde yayınlandığı, en } \\
\text { fazla bildirinin } 58 \text { bildiri ile 2018 Nisan ayında düzenlenen UTK'da } \\
\text { sunulduğuna dair bulgular ortaya koymuşlardır. }\end{array}$ \\
\hline
\end{tabular}


Turist Rehberliği Dergisi (TURED) \& Y1l. 2020, Cilt. 3, Sayı. 2

Journal of Tour Guiding (JOTOG) \& Year. 2020, Volume. 3, Issue. 2

Tablo 2. Ulusal Alanyazında Turist Rehberliği Alanı ile İlgili Hazırlanan Bibliyometrik Çalışmalar ve Bulguları (Devamı)

\begin{tabular}{|c|c|c|}
\hline Yazarlar & Konu & Bulgular \\
\hline $\begin{array}{c}\text { Özsoy \& } \\
\text { Çokal (2018) }\end{array}$ & $\begin{array}{l}\text { Türkiye'de turist } \\
\text { rehberliği alanında } \\
\text { yayımlanmış lisansüstü } \\
\text { tezlerin bibliyometrik } \\
\text { analizi (1989-2018) }\end{array}$ & $\begin{array}{l}\text { Konu ile alakalı en fazla katkının Balıkesir Üniversitesi'nden sağlandığı, } \\
\text { hazırlanan tezlerin çoğunlukla Turizm İşletmeciliği ve Otelcilik Ana Bilim } \\
\text { Dalı'nda yazıldığı, veri toplama tekniği olarak çoğunlukla anket tekniğinin } \\
\text { kullanıldığı bulgularını elde etmişlerdir. }\end{array}$ \\
\hline $\begin{array}{c}\text { Kaygalak \& } \\
\text { Kirlar (2019) }\end{array}$ & $\begin{array}{l}\text { Turizm rehberliği alanında } \\
\text { yapılan makalelerin } \\
\text { bibliyometrik analizi }\end{array}$ & $\begin{array}{l}\text { Turizm rehberliği alanında yapılan makalelerin bibliyometrik analizi ilgili ile } \\
\text { olan çalışmada, } 75 \text { makalenin bazı parametrelere göre değerlendirilmesi } \\
\text { yapılmış ve turizm rehberliği alanında en fazla makale yayını Annals of } \\
\text { Tourism Research ve Tourism Management dergilerinde yer aldığı, turizm } \\
\text { rehberliği alanında yapılan çalışmaların sayısında } 2000 \text { yllından itibaren bir } \\
\text { artış olduğu ve en sık işlenen konunun turist rehberlerinin rolleri olduğu } \\
\text { sonuçları elde edilmiştir. }\end{array}$ \\
\hline $\begin{array}{l}\text { Arıkan Saltık } \\
\text { (2020) }\end{array}$ & $\begin{array}{l}\text { Turist rehberliği konulu } \\
\text { ulusal lisansüstü tezlerin } \\
\text { bibliyometrik profili }\end{array}$ & $\begin{array}{l}\text { Çalışmada, } 1989 \text { ile } 2018 \text { y1lı arasında yazılmış } 94 \text { lisansüstü tez olduğu } \\
\text { belirlenmiştir. Tezler; eğitim düzeyi, tamamlandığı yıl, üniversite, ana bilim } \\
\text { dalı, danışman unvanı, sayfa sayısı, araştırma yöntemi, veri toplama tekniği } \\
\text { ve kaynağı olarak belirlenen ölçütler üzerinden bibliyometrik olarak analiz } \\
\text { edilmiştir. Araştırma sonucunda, turist rehberliği konulu lisansüstü tez } \\
\text { sayısının, turizm ve turist rehberliği alanında lisansüstü eğitimin gelişimine } \\
\text { paralel bir şekilde, } 2010 \text { yılından itibaren artış gösterdiği görülmüştür. } \\
\text { Toplamda } 28 \text { farklı üniversite bünyesinde turist rehberliği konulu lisansüstü } \\
\text { tez yazılmıştır. Doktora tezlerinin ağırlıklı olarak profesör unvanlı, yüksek } \\
\text { lisans tezlerinin doktor öğretim üyesi unvanlı öğretim üyeleri } \\
\text { danışmanlığında tamamlandığı belirlenmiştir. Lisansüstü tezlerin } \\
\text { çoğunluğunun nicel araştırma yöntemleriyle gerçekleştirildiği, ağırlıklı olarak } \\
\text { anket tekniği ile turist rehberlerinden veri toplandığ1 tespit edilen bulgular } \\
\text { arasındadır. }\end{array}$ \\
\hline $\begin{array}{l}\text { Zengin } \\
\text { \&Atasoy } \\
(2020)\end{array}$ & $\begin{array}{l}\text { Turizm rehberliği } \\
\text { alanındaki lisansüstü } \\
\text { tezlerin bibliyometrik } \\
\text { çerçevesi }\end{array}$ & $\begin{array}{l}\text { Bu araştırma kapsamında YÖKTEZ veri tabanında } 1989-2019 \text { yılları arasında } \\
30 \text { yıllık dönemde turizm rehberliği alanındaki yayımlanmış } 74 \text { yüksek lisans } \\
\text { ve } 13 \text { doktora tezi bazı ölçütler çerçevesinde incelenmiştir. Araştırma } \\
\text { kapsamında en çok lisansüstü tezin Balıkesir Üniversitesi SBE tarafindan } \\
\text { yayımlandığı tespit edilmiştir. Ayrıca sırasıyla Nevşehir Hacı Bektaş Veli, } \\
\text { Gazi ve Akdeniz Üniversiteleri turizm rehberliği alanına katkı sağlayan } \\
\text { önemli üniversiteler arasında olduğu, lisansüstü tezlerin yılllara göre dağılımı } \\
\text { kapsamında 2015-2019 yılları arasında büyük bir artışı olduğu gibi } \\
\text { sonuçlara ulaşılmıştır. }\end{array}$ \\
\hline
\end{tabular}

\section{Yöntem}

\subsection{Araştırmanın Amacı}

Çalışmada, 1989 yılından 2019'a kadar Ulusal Tez Merkezi'nde yayınlanan turizm rehberliği alanı ile ilgili hazırlanmış, erişime açık doktora ve yüksek lisans tezleri incelenmiştir. Bu bağlamda araştırmanın amacı, 1989-2019 yılları arasında turizm rehberliği alanı ile ilgili yapılan lisansüstü tezlerin bibliyometrik özelliklerini ortaya koyarak ilgili bilgi birikimine bütünsel bir bakış açısı kazandırmaktır.

\subsection{Araștırmanın Deseni}

Bu çalışmada nitel araştırmalarda veri toplama yöntemlerinden biri olan doküman incelemesi (Yıldırım \& Şimşek, 2018) verinin çözümlenmesinde ise bibliyometri tekniği kullanılmıştır. Bibliyometri, sayım yapmaya dayalı bir inceleme tekniği olup, yayınlanmış kitap, dergi, makale ve tez gibi çıktıların matematiksel ve istatistiksel tekniklerle incelenmesi (Pritchard, 1969: 349), en sık kullanılan kaynakların tespiti ve literatürdeki yaşlanma hızının saptanmasına dayanmaktadır (Al \& Coştur, 2007: 144). Bibliyometrik analiz, yayınlanmış olan kaynaklardan toplanan verinin nicel analizini yaparak, alandaki örüntülerini incelemekte ve bir akademik alandaki entelektüel gelişimi 
hakkında bilgi vermektedir (Lee, 2015: 17). Diodata (1994: vii), bibliyometriyi, sayımdan analize kadar matematiksel ve istatistiksel teknikleri kullanan, bilginin açığa çıkarılabilmesi için ilişki modellerini inceleyen bir alan olarak ifade etmektedir. Bu analiz, çalışmaların yıl, dergi, konu, yazar sayısı, yayın bilgisi, kaynak sayısı, örneklem büyüklüğü gibi belirli özelliklerinin analizi (Ayaz \& Türkmen, 2018: 23) ile elde edilen istatistiksel sonuçlar doğrultusunda belirli bir disipline ait genel yapının ortaya konulmasını mümkün kılmaktadır. Wallin (2005: 261), bu yöntemin temel amacını, somut olmayan niteliklerin, somut ve dolayısıyla yönetilebilir hâle getirilmesi şeklinde ifade etmektedir.

Bibliyometrik analiz yöntemleri farklı şekillerde gerçekleştirilebilmektedir (Koseoglu, et al., 2016: 181). Bunlardan bir tanesi basit bibliyometrik analizler olarak bilinmekte ve içerik analizi ve farklı analizler yoluyla çalışmaların veya çalışmaya katkıda bulunanların performanslarını ölçmeye dayanmaktadır (Garfield, 1979: 360). İkincisi ise, atıf analizi, ortak atıf analizi, kitap, makale, patent gibi çalışmalar ile ilgili çalışma yapan araştırmacıları kategorilere ayırmaktadır (Koseoglu, et al., 2015). Tüm bu aşamalarda ise sistematik bir yöntem izleyen bu analiz tekniği güvenirlik sorularına da cevap vermektedir.

Bibliyometrik teknik kullanılarak yapılan analizler, bir derginin iç değerlendirmesine yönelik olarak mikro düzeyde olabileceği gibi bir ülkenin bilim politikasına şekil vermek amacıyla makro düzeyde de yapılabilmektedir (Karagöz \& Kozak, 2014: 48). Dolayısıyla çok büyük kaynakların incelenmesini gerektiren çalışmalarda bibliyometrik analizler araştırmacılara büyük avantaj ve kolaylık sağlamaktadır.

Bibliyometrik bir çözümleme, literatür birikiminin tümünü veya belli bir kesitini ele almakta, ilgili disiplinin zaman ve mekandaki devinimiyle ilgili somut veri sunarak genellemeler yapmaktadır. Ayrıca ilgili bilim dalının gelecekteki muhtemel yönelimine dair çıkarımlarda bulunulmasına yardımc1 olmaktadır (İnceoğlu, 2014: 34). Literatür birikiminin bir bütün veya kesitli olarak ele alınması ise çalışmanın varsayımıyla doğrudan ilişkilidir. Lisansüstü çalışmaların farklı bilimsel çalışmalara yol açacağı varsayımına dayanarak sadece lisansüstü tezlerin incelenmesine dayalı olarak çalışmalar hazırlanabilmektedir.

\subsection{Araştırmanın Örneklem Çerçevesi ve Örneklemi}

Araştırma sonuçlarının daha anlamlı, evreninin mümkün olduğunca tamamının temsili ile daha kesin sonuçlar elde edilmesi amacıyla çeşitli şekillerde taramalar gerçekleştirilmiştir. Lisansüstü tezlerin taranabilmesi için tez arama motoruna "turizm rehberliği", "turist rehberliği", "tur rehberliği", "tourist guide”, "tour guide”, "tour leader" gibi Türkçe ve Türkçe anahtar kelimeler yazılarak tarama gerçekleştirilmiştir. Belirli aralıklarla yapılan tarama sonucunda 105 yüksek lisans, 21 doktora tezine ulaşılmıştır. 105 yüksek lisans tezinin tamamına ulaş1lırken, üç doktora tezinin yazarı tarafından erişime kapatılmasından dolayı tezler bu çalışmanın örneklemine dâhil edilememiştir. Ayrıca bir doktora tezi, üç yüksek lisans tezinin Ulusal Tez Merkezi veri tabanı üzerinden yayınlanma izni bulunmaması nedeniyle bu tezlere Erciyes Üniversitesi Kütüphanesi aracılığıyla TÜBESS üzerinden erişim sağlanmıştır. Bu kapsamda örneklem olarak belirlenen erişime açık 123 adet lisansüstü tez, sosyal bilimler için geliştirilmiş istatistik programına yüklenerek bazı parametreler çerçevesinde analiz edilmiştir.

Lisansüstü tezlerin bibliyometrik özelliklerinin incelenmesi için belirlenen araştırmaları soruları şu şekildedir:

a. Turist rehberliği ile ilgili lisansüstü çalışmalar yıllara, türlerine, üniversitelere, enstitülere ve ana bilim dallarına göre nasıl bir dağılım göstermektedir?

b. Turist rehberliği ile ilgili lisansüstü çalışmalar danışman unvanına, örneklem alanına, araştırma türüne, araştırma desenine ve örneklem sayısına göre nasıl bir dağılım göstermektedir? 


\section{IIIIII $\odot$}

Turist Rehberliği Dergisi (TURED) \& Y1l. 2020, Cilt. 3, Sayı. 2

Journal of Tour Guiding (JOTOG) \& Year. 2020, Volume. 3, Issue. 2

c. Turist rehberliği ile ilgili lisansüstü çalışmalar uygulama kitlesi, veri toplama aracı, Türkçe ve yabancı kaynak sayısı, toplam sayfa sayısı, konusu ve anahtar kelimeler bölümünde en s1k tekrar eden kelimelerine göre nasıl bir dağılım sergilemektedir?

d. Bu kapsamda erişime açık olan toplam 123 adet lisansüstü tez, yüzde ve sıklık değerleri dikkate alınarak analiz edilmiştir.

\section{Bulgular}

Ulusal Tez Merkezi tarandığında, turist rehberliği üzerine 1989-2019 yılları arasında 21 doktora, 105 yüksek lisans tezi hazırlanmıştır. Bu tezlerden üç doktora tezi, yazarı tarafından belirli bir süre erişime kısıtlanmasından dolayı araştırmaya dâhil edilememiştir. Bu kapsamda araştırmaya dâhil edilen 18 doktora, 105 yüksek lisans tezi bulunmaktadır. Bu bölümde, belirlenen parametreler ışığında, ilgili lisansüstü tezlerin analizleri ile elde edilen yüzde ve sıklık değerlerinin yorumlanması ve ilgili çalışmalarla karşılaştırma yaparak değerlendirilmesine yer verilecektir.

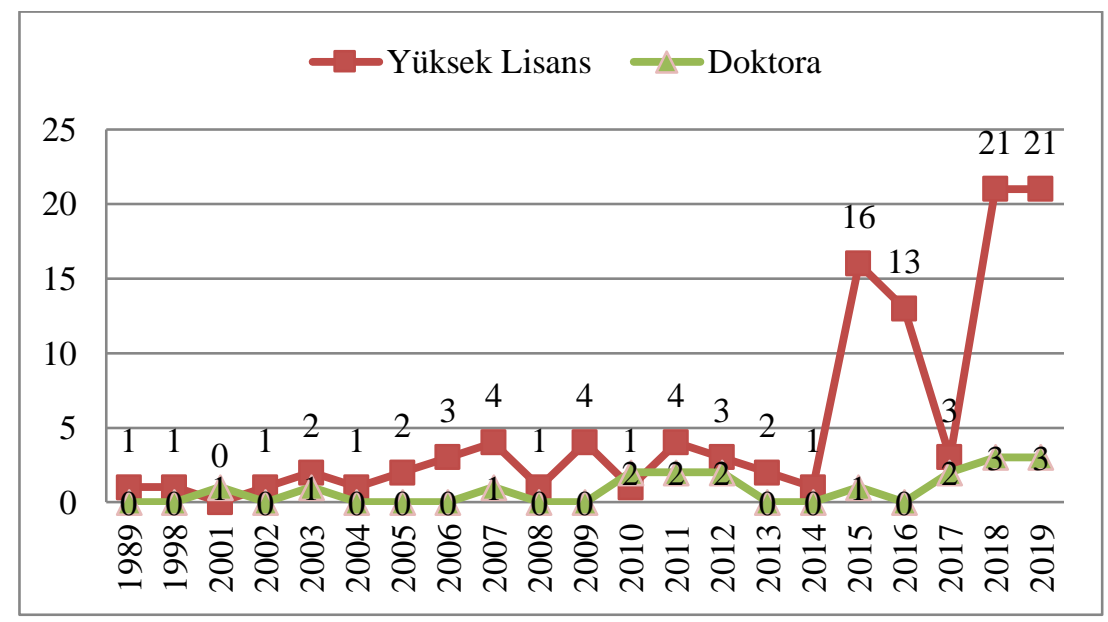

Şekil 1: Lisansüstü Tezlerin Yıllara Göre Dağılımı

Turizm rehberliği alanı ile ilgili yapılan lisansüstü tezlerin yıllara göre dağılımı incelendiğinde, Ulusal Tez Merkezi’nde taranan konu ile alakalı ilk tezin 1989 yılında yüksek lisans tezi olarak hazırlandığı sonucuna ulaşılmaktadır. İlgili alanla ilgili ilk doktora tezi ise 2001 yılında hazırlanmıştır. 1989-1998 ve 1998-2001 yılları arasında alanla ilgili herhangi bir tezin yayınlanmamış ve bu yıl aralıkları haricinde her yıl düzenli bir şekilde olmasa da tezlerin yayınlanmış olduğu dikkat çekmektedir. Özellikle 2015 yılı ve sonrasında turist rehberliği ile ilgili yapılan yüksek lisans tezlerinin sayısında bir artış görülmektedir. 2018 yılı itibariyle ise doktora tez sayısında bir artış gözlenmiştir. 2018 ve 2019 yılları hem yüksek lisans (21) hem de doktora (3) tez sayısında en fazla artışın olduğu yıllardır. Arıkan Saltık (2020) ise çalışmasında ilgili alanda en fazla tezin 2015 (16 adet) yılında yazıldığı sonucuna ulaşmıştır. Bu araştırmada ise en fazla tez oranı 2018 ve 2019 yıllarına aittir. Bu çalışmada yıllara ait bir diğer bulgu ise ilk doktora tezinin 2001 yılında yayınlandığıdır. Arıkan Saltık (2020) ise çalışmasında ilk doktora tezinin 2003 yılında yazıldığını ifade etmektedir. Zengin ve Atasoy (2020) ise son yıllarda lisansüstü tezlerde bir artı̧̧ gözlendiğini tespit etmiş fakat tezlerin yıllara göre dağılımında bu çalışmada olduğundan daha az sayıda tez bulgusuna ulaşmışlardır. Örneğin, Zengin ve Atasoy (2020) 2011 yılı lisansüstü tezlerinin sayısını bir olarak belirlemişken bu araştırmada 2011 yılında ilgili alanda altı lisansüstü tezin hazırlandığı belirlenmiştir. Çapar vd. (2018) ise ilk ulusal tezin 2005 yılında hazırlandığı sonucuna ulaşmışlardır. Bu anlamda turist rehberliği alanında lisansüstü tezlerin yıllara göre dağılımında Çapar vd. (2018), Arıkan Saltık (2020), Zengin ve Atasoy (2020)'un çalışmasında belirtilen oranlarla bu çalışmadaki 


\section{IIIIII $\odot$}

Turist Rehberliği Dergisi (TURED) \& Y1l. 2020, Cilt. 3, Sayı. 2

Journal of Tour Guiding (JOTOG) \& Year. 2020, Volume. 3, Issue. 2

bulgular farklılık göstermektedir. Fakat tüm çalışmalarda fikir birliğine varılan konulardan bir tanesi 2010 (özellikle 2015) yılından itibaren ilgili alanla ilgili çalışmalara daha fazla yer verildiğidir. Diğer yıllara ait sonuçlar Şekil 1'de gösterilmektedir.



Şekil 2: Lisansüstü Tezlerin Türüne İlişkin Dağılım

Turizm rehberliği alanında 1989-2019 yılları arasında erişime açık toplamda 123 lisansüstü tez bulunmaktadır. Tezlerin \%86,1'i yüksek lisans (105), \%13,9'u ise doktora (18) tezidir. İlgili alanın doktora programının bulunmaması yüzde dağılımındaki dengesizliğin bir nedeni olarak ifade edilebilir. Arıkan Saltık (2020), çalışmasında 1989-2018 yılı arasında 94 lisansüstü teze ulaşırken Zengin ve Atasoy (2020) ise 1989-2019 yılları arasında 87 teze ulaşmıştır. Çapar vd. (2018) ise 20052017 yılları arasında 40 tezin yazıldığı sonucuna ulaşmaktadır. Bu anlamda tezlerin taranması açısından bu çalışmanın diğer çalışmalarla arasında bir farklılı̆̆ın bulunduğu ifade edilmelidir. Şekil 3 ’te lisansüstü tezlerin üniversitelere göre dağılımı gösterilmektedir.

Araştırmada kullanılan parametrelerden bir diğeri turist rehberliği alanı ile ilgili yapılan tezlerin üniversitelere göre dağılımıdır. Şekil 3 incelendiğinde, Balıkesir Üniversitesi konu ile alakalı 23 yüksek lisans, üç doktora tezinin yayınlandığı $(\% 21,9)$ üniversitedir. Ayrıca doktora tezlerinin sayıları açısından değerlendirildiğinde ise Gazi/Hacı Bayram Veli Üniversitesi ile yine ilk sırada yer almaktadır. \% 7,6'lık bir oran ile yüksek lisans tez sıralamasında Gazi/Hacı Bayram Veli Üniversitesi ikinci sırada, Mersin Üniversitesi ve Nevşehir Hacı Bektaş Veli Üniversitesi ise yedi yüksek lisans tezi ile üçüncü sırada yer almaktadır. Lisansüstü tezlerin ağırlıklı olarak Balıkesir Üniversitesi, Gazi/Hacı Bayram Veli Üniversitesi, Aydın Adnan Menderes Üniversitesi, Mersin Üniversitesi ve Nevşehir Hac1 Bektaş Veli Üniversitesi olarak beş üniversite bünyesinde toplandığ 1 sonucuna ulaşılmıştır. Çapar, Toksöz ve Dönmez (2018), Özsoy ve Çokal (2019), Zengin ve Atasoy (2020), Arıkan Saltık'ın (2020) bulguları ile de paralellik gösteren bu sonucun bu üniversitelerin turizm eğitiminde eski ve köklü bir geçmiş̧leri olmasından kaynaklandığı ifade edilebilir. Üniversitelere ait diğer bilgiler Şekil 3’te yer almaktadır. 


\section{IIIIII)}

Turist Rehberliği Dergisi (TURED) \& Y11. 2020, Cilt. 3, Sayı. 2

Journal of Tour Guiding (JOTOG) \& Year. 2020, Volume. 3, Issue. 2

\section{— Yüksek Lisans — Doktora}

Süleyman Demirel Üniversitesi Orta Doğu Teknik Üniversitesi

Mustafa Kemal Üniversitesi

Mimar Sinan Güzel Sanatlar Üniversitesi

Kırklareli Üniversitesi

Kastamonu Üniversitesi

Kafkas Üniversitesi

Kahramanmaraş Sütçü İmam Üniversitesi

Harran Üniversitesi

Gaziantep Üniversitesi

Beykent Üniversitesi

Batman Üniversitesi

Atatürk Üniversitesi

Alanya Alaaddin Keykubat Üniversitesi

Selçuk Üniversitesi

Hacettepe Üniversitesi

Erciyes Üniversitesi

Dokuz Eylül Üniversitesi

Çanakkale Onsekiz Mart Üniversitesi

Boğaziçi Üniversitesi

Afyon Kocatepe Üniversitesi

Yüzüncü Y1l Üniversitesi

Eskişehir Osmangazi Üniversitesi

Sakarya Üniversitesi

İzmir Kâtip Çelebi Üniversitesi

İstanbul Üniversitesi

Anadolu Üniversitesi

Akdeniz Üniversitesi

Ege Üniversitesi

Nevşsehir Hac1 Bektaş Veli Üniversitesi

Mersin Üniversitesi

Aydın Adnan Menderes Üniversitesi

Gazi Üniversitesi/Hacı Bayram Veli.

Balıkesir Üniversitesi

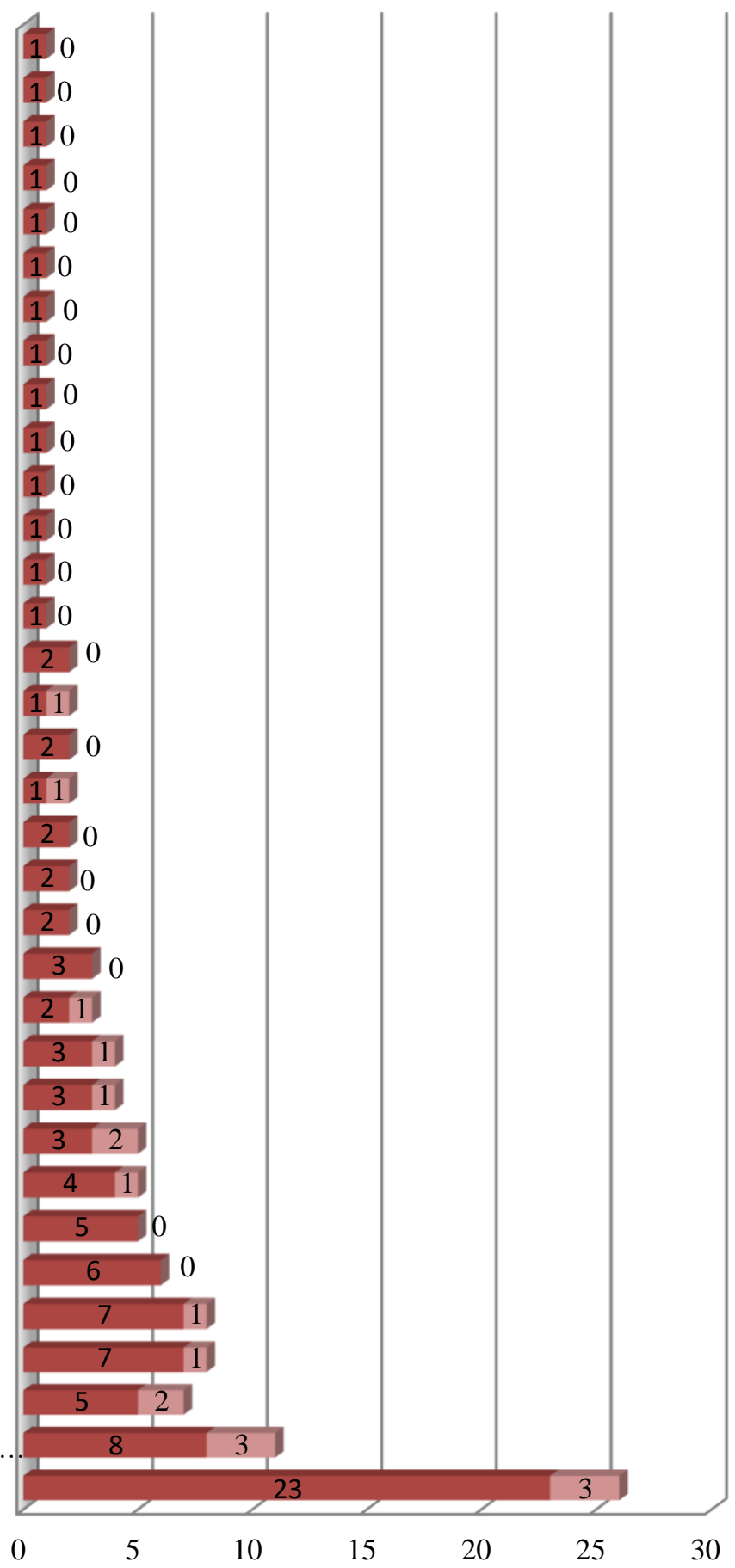

Şekil 3: Lisansüstü Tezlerin Üniversitelere Göre Dağılımı 


\section{IIIIII $\odot$}

Turist Rehberliği Dergisi (TURED) \& Y1l. 2020, Cilt. 3, Sayı. 2

Journal of Tour Guiding (JOTOG) \& Year. 2020, Volume. 3, Issue. 2

Şekil 4'te tezlerin bağlı olduğu enstitülerin yüksek lisans ve doktora tezlerine göre dağılımı gösterilmektedir. Tezlerin bağlı olduğu enstitüler incelendiğinde, konu ile ilgili tezlerin en fazla Sosyal Bilimler Enstitüsü bünyesinde hazırlandığı sonucuna ulaşılmaktadır. Turist rehberliği alanının büyük oranda sosyal bilimler alanıyla ilgili olmasından dolayı sonucun olağan olduğu yorumunda bulunabilir. Ayrıca Turizm İşletmeciliği Ana Bilim Dalı'nın Sosyal Bilimler Enstitüsü bünyesinde bulunduğu ve turist rehberliği ile ilgili yapılan çalışmaların daha çok bu bilim dalı altında hazırlandığı (Bkz. Şekil 5) göz önüne alındığında şekil daha iyi anlaşılabilmektedir.

Yüksek lisans tezlerinin \%2,8' lik kısmının, doktora tezlerinin ise \%11,7'lik kısmının Eğitim Bilimleri Enstitüsü bünyesinde hazırlanmış olduğu ulaşılan sonuçlar arasındadır. Ayrıca Lisansüstü Eğitim Enstitüsü* ve Fen Bilimleri Enstitüsü bünyesinde hazırlanan tezler de araştırmanın örneklemi arasında yer almaktadır. Fen Bilimleri Enstitüsü, turizm rehberliği alanıyla ilgisi olmayan bir ana bilim dalı gibi görünse dahi bünyesinde hazırlanan tezlerin genellikle turist rehberliğine ilişkin sanal/mobil ürün geliştirmeye yönelik olarak hazırlanmış olduğu ifade edilebilir.



Şekil 4: Lisansüstü Tezlerin Bağlı Olduğu Enstitü

Şekil 5'te tezlerin bağlı olduğu ana bilim dalları verilmektedir. Tabloya göre 49 yüksek lisans 10 doktora tezinin bünyesinde bulunduğu Turizm İşletmeciliği Ana Bilim Dalı ilk sırada, Turizm İşletmeciliği ve Otelcilik Ana Bilim Dalı ise toplamda 21 tez ile ikinci sırada yer almaktadır. 2016 yılından itibaren öğrenci alımına başlayan Turizm Rehberliği Ana Bilim Dalı yüksek lisans programları henüz 2015 yılında öğrenci alımına başlamasına karşın 10 adet yüksek lisans tezi ile üçüncü sırada bulunmaktadır. İlgili ana bilim dalının doktora programı bulunmamasından dolayı bu dalda doktora tezi bulunmamaktadır. Dördüncü sırada ise üç doktora, üç yüksek lisans tezinin bağlı bulunduğu Turizm İşletmeciliği Eğitimi Ana Bilim Dalı bulunmaktadır. Ayrıca, multidisipliner bir alan olarak turizm rehberliği alanının (Zilinger, Jonasson \& Adolfsson, 2012) doğrudan bir bağlantısının olmadığı Şehir ve Bölge Planlama, Sistem ve Kontrol Mühendisliği, Sosyal Psikoloji, Maliye, Biyomühendislik ve Bilimleri, Batı Dilleri ve Edebiyatları gibi farklı ana bilim dallarında da çalışılan bir konu olduğu sonucuna ulaşılmıştır. Bu anlamda bulgular Zengin ve Atasoy (2020) ve Özsoy ve Çokal (2019)'un bulguları ile paralellik göstermektedir. Arıkan Saltık (2020) ise çalışmasında tezlerin yalnızca turizm ile ilgili ana bilim dallarında yer aldığı sonucuna ulaşmıştır ve bu nedenle sonuç farklılaşmıştır.

\footnotetext{
* Bu enstitü, 2018 yılında Gazi Üniversitesi'nden ayrılarak kurulan Ankara Hacı Bayram Veli Üniversitesi bünyesinde yer almaktadır. Dolayısıyla 2018 yılından sonra yayınlanan tez bu enstitüye dâhil edilmiştir.
} 


\section{IIIIII $\odot$}

Turist Rehberliği Dergisi (TURED) \& Y11. 2020, Cilt. 3, Sayı. 2

Journal of Tour Guiding (JOTOG) \& Year. 2020, Volume. 3, Issue. 2

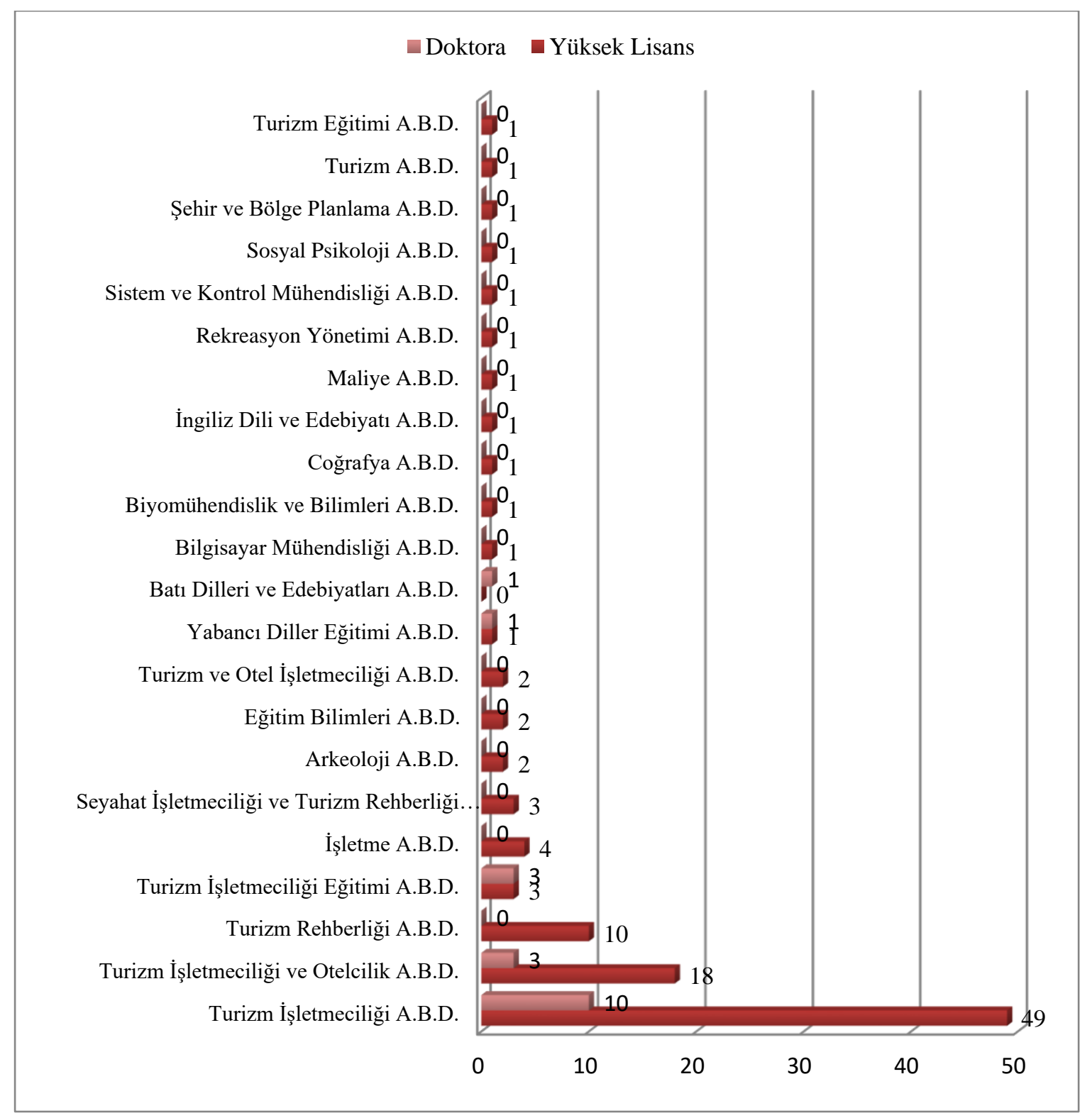

Şekil 5: Lisansüstü Tezlerin Ana Bilim Dalına Göre Dağılımı

Lisansüstü tezlerin danışman unvanlarına göre dağılımını belirlemek amacıyla yapılan analiz sonucunda, yüksek lisans tezi yürüten danışmanlarının en fazla doktor öğretim üyesi $(\% 40,9)$, doktora tezi yürüten danışmanların ise en fazla profesör unvanına (\%77) sahip olduğu sonucuna ulaşılmaktadır. Arıkan Saltık ve Alimanoğlu'nun (2018) çalışmalarında dayanarak, doktora programı açma ve danışmanlık yapma konusunda unvanı da kapsayan ön koşulların olduğu göz önüne alındığında, doktora düzeyindeki tezlerin genelinin doçent doktor ve profesör danışmanlığında tamamlanmasının doğal olduğu söylenebilir. Bu sonuç, Arıkan Saltık (2020) çalışmasındaki bulgular ile benzerlik gösterirken diğer çalışmalarda doktora ve yüksek lisans olarak kategorilere ayrılmadığı için bir karşılaştırma yapmak mümkün olamamaktadır. Doktora tezine danışmanlık eden bir doktor öğretim üyesi bulunurken, yüksek lisans tezine danışmanlık eden 43 doktor öğretim üyesi bulunmaktadır. Üç doktora ve 38 yüksek lisans tezinde doçent doktor unvanına sahip akademisyenlerin tezleri yönettiği Şekil 6' da gösterilmektedir. 


\section{IIIII) $\odot$}

Turist Rehberliği Dergisi (TURED) \& Y11. 2020, Cilt. 3, Sayı. 2

Journal of Tour Guiding (JOTOG) \& Year. 2020, Volume. 3, Issue. 2



Şekil 6: Lisansüstü Tezleri Yürüten Danışmanların Unvanlarına Göre Dağılım

Şekil 7'de çalışmaların uygulama alanlarına göre dağılımı verilmektedir. Çalışmaların uygulama alanı, tezlerde belirtildiği şekliyle grafikleştirilmiş̧ir. Bu nedenle sadece il bazında yapılan çalışmalar bölgelere dâhil edilmemiştir. Örneğin, Nevşehir ili kapsamında yapılan çalışmalar Kapadokya Bölgesi içerisinde verilmemektedir. Buradan hareketle ş̧ekil incelendiğinde, çalışmalarda büyük oranda (yüksek lisans tezlerinde $\% 49,5$; doktora tezlerinde $\% 76,4$ ) Türkiye geneli üzerinden örneklem seçiminin yapılmış olduğu sonucuna ulaşılmaktadır. Lisansüstü tezlerin bazılarında kavramsal bir çalışma türü, bazılarında somut ürün geliştirme gibi tekniklerin uygulanmasından dolayı herhangi bir örneklem alanı seçimine gidilmemiş olduğu şekilde gösterilmektedir.

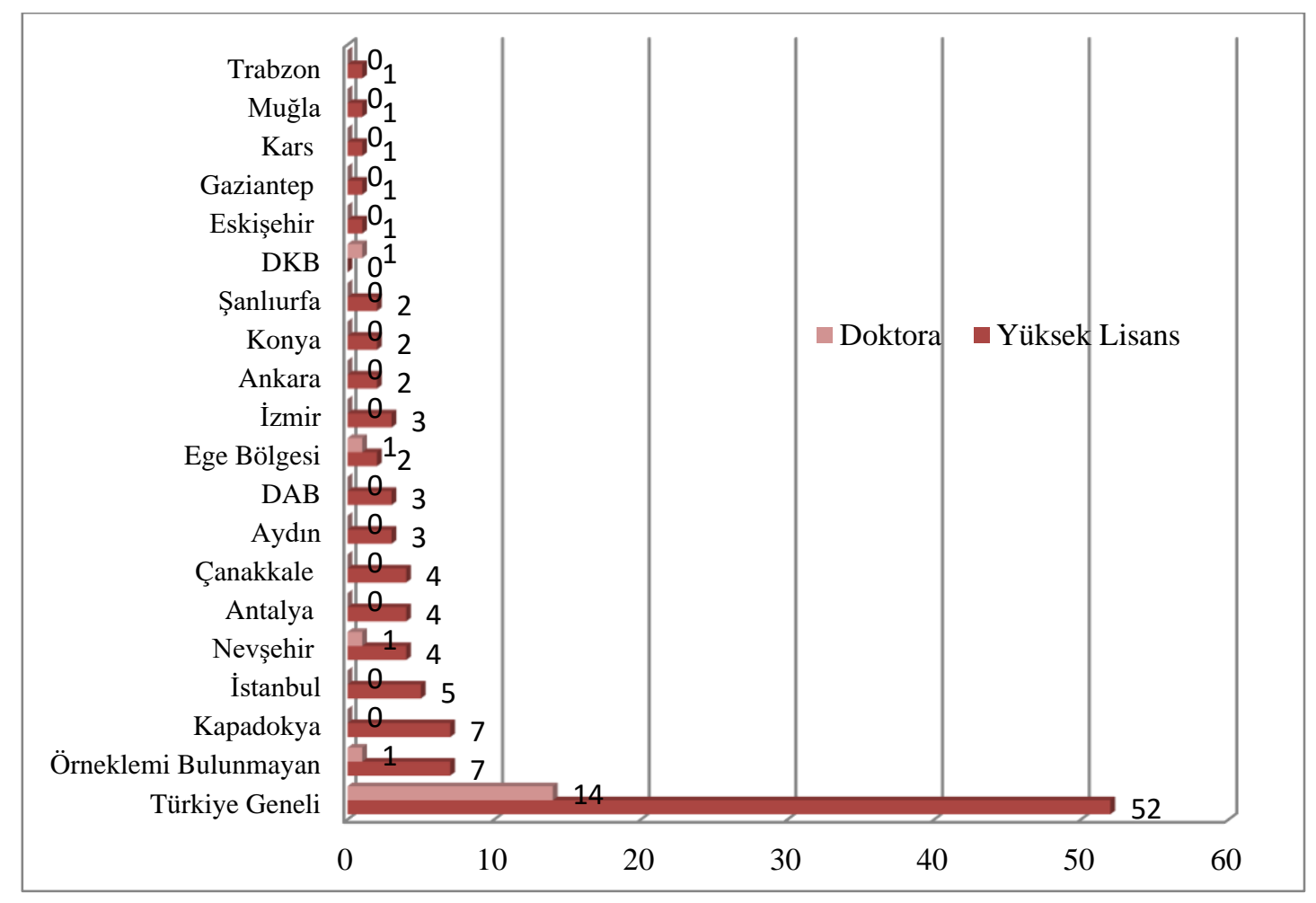

Şekil 7: Lisansüstü Çalışmalarda Seçilen Örneklem Alanı 


\section{IIIII) $\odot$}

Turist Rehberliği Dergisi (TURED) \& Y1l. 2020, Cilt. 3, Sayı. 2

Journal of Tour Guiding (JOTOG) \& Year. 2020, Volume. 3, Issue. 2

Yüksek lisans tezlerinde örneklem alanı olarak en fazla Kapadokya Bölgesi, Nevşehir, Antalya, Çanakkale, Aydın ve Doğu Anadolu Bölgesi (DAB) bulunurken, doktora tezlerinde Nevşehir, Ege Bölgesi, Doğu Karadeniz Bölgesi (DKB) birer kez örneklem alanı olarak seçilmiştir. Bu sonucun veri toplama açısından kolaylık sağlayacağı düşüncesinden yola çıkılarak, turistik olarak daha gelişmiş bölgelerin seçilmesinden kaynaklı olduğu düşünülmektedir.



Şekil 8: Lisansüstü Tezlerin Araştırma Türüne Göre Dağılımı

Şekil 8, lisansüstü tezlerin alan araştırması şeklinde veya sadece ikincil veriye dayalı olarak gerçekleştirildiğinin belirlenmesi amaciyla grafikleştirilmiştir. Şekil incelendiğinde, lisansüstü tezlerin büyük oranda (yüksek lisans $\% 96,1$; doktora \%94,4) uygulamaya dayalı olarak yapıldığ 1 dikkat çekmektedir. Bu anlamda turizm rehberliği alanı ile ilgili yapılan lisansüstü tezlerin büyük çoğunluğunun alan araştırması şeklinde yapıldığı anlaşılmaktadır. Kavramsal olarak hazırlanan ise dört yüksek lisans, bir doktora tezinin bulunduğu bulgular arasındadır.



Şekil 9: Lisansüstü Tezlerde Benimsenen Araştırma Desenine Göre Dă̆glım

Tezlerin büyük çoğunluğunun nicel araştırma teknikleri kullanılarak gerçekleştirildiği görülmektedir. Şekil 12'de de görüleceği üzere, turist rehberliğini konu alan çalışmalarda anketin sıkça başvurulan bir veri toplama tekniği olarak kullanılması bu sonucu doğrular niteliktedir. Turizm ile ilgili araştırmalarda sağladığı bazı avantajlardan dolayı nicel tekniklerin sıklıkla kullanıldığı bilinmektedir (İçöz \& Başarır, 1996). Fakat son zamanlarda nitel ve karma yöntemlerin de ön plana çıktı̆̆ ifade edilebilir. Nitel yöntemlerin sıklıkla tartışılan güvenirlik ve geçerlik sorunu, nicel yöntemlerin ise ifade özgürlüğünden uzak olmasının eleştirileri karma 


\section{IIIII) $\odot$}

Turist Rehberliği Dergisi (TURED) \& Y1l. 2020, Cilt. 3, Sayı. 2

Journal of Tour Guiding (JOTOG) \& Year. 2020, Volume. 3, Issue. 2

yöntemlerin önem kazanmasına büyük oranda zemin hazırlamıştır (Decrop, 1999). Şekil 9'da üç yüksek lisans ve üç doktora tezinde karma yöntemin kullanıldığı gösterilmektedir.



Şekil 10: Lisansüstü Tezlerin Örneklem Büyüklüklerine Göre Dağılımı

Tezlerin örneklem büyüklükleri ele alındığında, yüksek lisans tezlerinde örneklem büyüklüğü en fazla 301-400 örneklem sayısı aralığında yer alırken, doktora tezlerinde bu sayının 401-500 arasında olduğu görülmektedir. Örneklem büyüklüğünün 100 ve altında olması nicel araştırmalar için yetersiz olarak ifade edilse de incelenen tezler arasında verinin mülakat, Delphi, yarı yapılandırılmış soru formu gibi tekniklerle toplandığı çalışmalar bulunmasından dolayı örneklem büyüklüğ̈̈nün kabul edilebilir düzeyde olduğu yorumu yapılabilir.

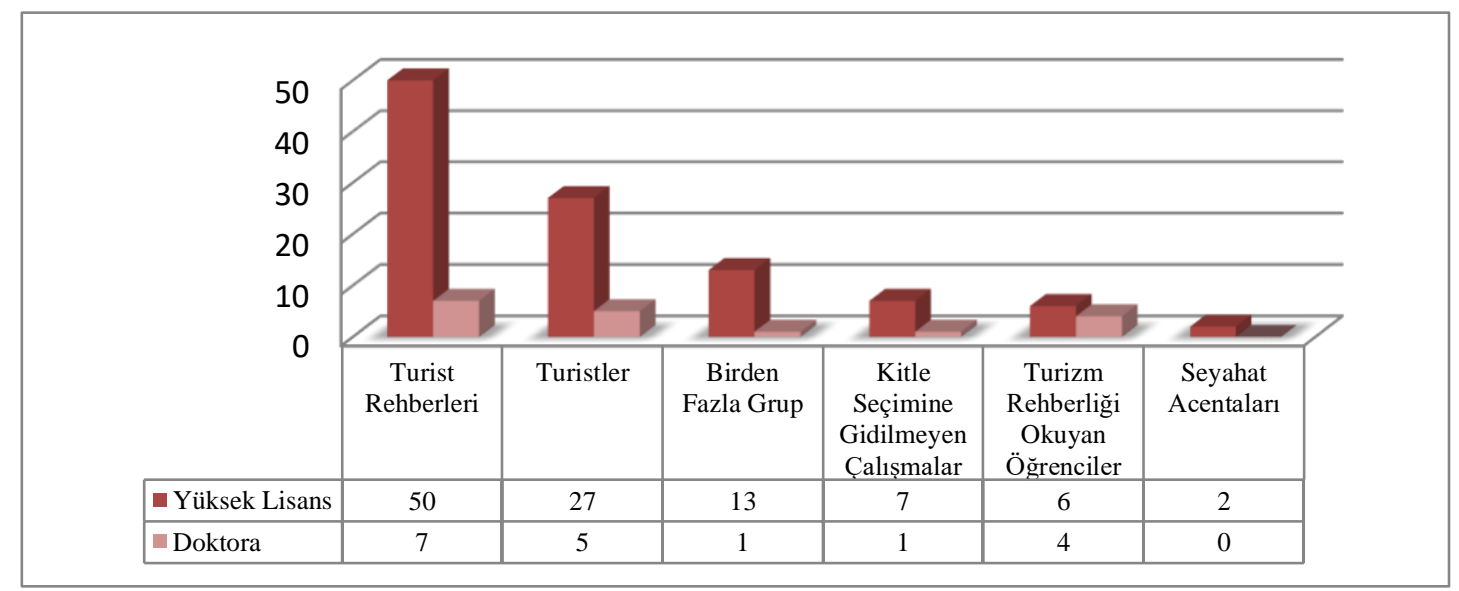

Şekil 11: Lisansüstü Tez Verisinin Toplandığı Kitle Dağılımı

Şekil 11 incelendiğinde, 50 yüksek lisans, 7 doktora tezinde en sık örneklem olarak seçilen grup, turist rehberlerinden oluşturmaktadır. Bu sonuç, diğer çalışmalardaki (Özsoy \& Çokal, 2018; Kaygalak \& Çelebi, 2019; Arıkan Saltık, 2020) bulgularla paralellik göstermektedir. Turist rehberlerinden sonra ise bu oranı, her iki tez türünde de turistler takip etmektedir. Bu sonucun tezlerin konusundan kaynaklı doğal olduğu söylenebilir. Altı çalışmada ise ikincil veriye dayalı, göstergebilim gibi tekniklerle veri toplandığ 1 için herhangi bir kitle seçimine gidilmemiş olduğu ulaşılan sonuçlar arasındadır. Bu anlamda ise çok disiplinli bir alan olan turist rehberliğinin (Zilinger, Jonasson \& Adolfsson, 2012) farklı örneklemlerde veya farklı yöntemlerde çalışılması konunun çok 
Turist Rehberliği Dergisi (TURED) \& Y1l. 2020, Cilt. 3, Sayı. 2

Journal of Tour Guiding (JOTOG) \& Year. 2020, Volume. 3, Issue. 2

boyutlu ele alınması ve farklı alanlardaki yaygın etkisini artırılarak kaynak çeşitlendirmesine gidilmesi açısından önemlidir.

Tezlerde kullanılan veri toplama teknikleri Şekil 12'de gösterilmektedir. Nicel yöntemlerin kullanımında sıkça başvurulan bir teknik olan anket tekniği, hem yüksek lisans $(\% 77,1)$ hem de doktora $(\% 76,4)$ tezlerinde en yüksek oranda kullanılan veri toplama tekniği olarak belirlenmiştir. Nicel ve nitel yöntemlerin bir arada kullanıldığı dördü yüksek lisans ikisi doktora olmak üzere altı lisansüstü tez bulunmaktadır. Analizlerden elde edilen bir diğer sonuç ise, iki yüksek lisans tezinin herhangi bir veri toplama yöntemine gitmeksizin somut bir mobil turist rehberi geliştirmesi çalışmasıdır. Ayrıca bir doktora tezinde gözlem, odak görüşmesi, yapılandırılmış görüşme, katılımlı gözlem, yarı yapılandırılmış görüşme gibi birden fazla nitel yöntemin bir arada kullanılmış olduğu da bulgular arasinda yer almaktadır.

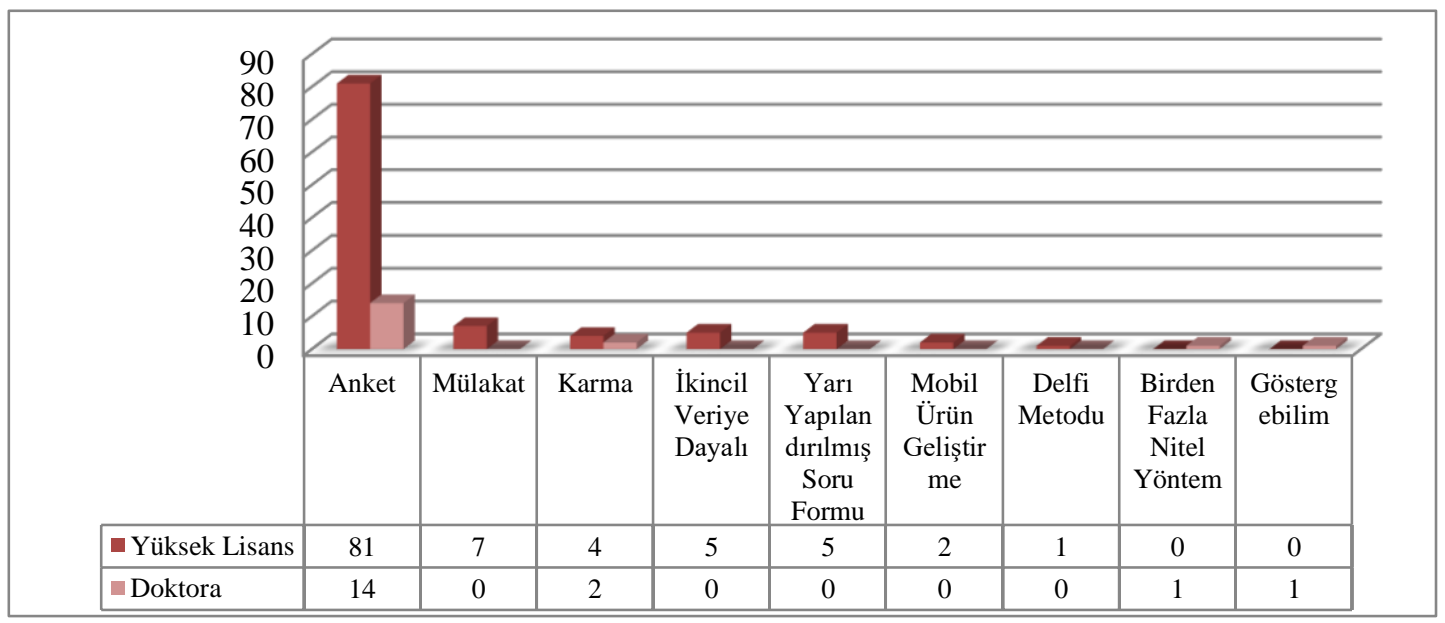

Şekil 12: Lisansüstü Tezlerde Kullanılan Veri Toplama Tekniği

Hazırlanan diğer çalışmalarda (Şahin \& Acun, 2015a; Çapar, Toksöz \& Dönmez, 2018; Özsoy \& Çokal, 2019; Zengin \& Atasoy 2020; Arıkan Saltık, 2020) gerek bildirilerde gerekse lisansüstü tezlerde veri toplama tekniği olarak nicel yöntemlerin daha çok tercih edildiği sonucuna ulaşılmıştır. Kaygalak ve Çelebi (2019) ise inceledikleri turist rehberliği alanı ile ilgili makalelerde daha çok nitel yöntemlerin kullanıldığı sonucuna ulaşmışlardır. Nitel yöntemlerin ilgili alanda bu derece sınırlı sayıda kullanılmasının nedenlerinden biri de nitel yöntemlerin sıklıkla tartışılan güvenirlik ve geçerlik sorunundan (Decrop, 1999) veya turizm alanındaki istatistiklerin yetersizliğinden kaynaklı olarak birincil veri elde etme konusunda en etkin yolun anket tekniğinin olduğunun düşünülmesinden (İçöz \& Başarır, 1996) kaynaklı olabileceği ifade edilebilir. Bulgulara dayanarak tezlerde hem nitel yöntemlerin hem de karma yöntemlerin geri planda kaldığı söylenebilir. Örneğin, Delphi metodunu kullanan sadece bir çalışmaya rastlanması bu duruma örnek olarak gösterilebilir. Lisansüstü çalışmalarda kullanılan yöntemlerin çeşitliği, konuların zenginliği, farklı tekniklerle veri toplanması alanla ilgili yapılacak diğer bilimsel çalışmalara fikir vermesi açısından önem arz edebilir.

Lisansüstï tezlerin Türkçe ve yabancı kaynak sayısına göre dağılımı incelendiğinde, 105 yüksek lisans tezinde Türkçe kaynak sayısı 12.606 iken bu sayı 18 doktora tezinde 3.706 olarak belirlenmiştir. 


\section{IIIII) $\odot$}

Turist Rehberliği Dergisi (TURED) \& Y1l. 2020, Cilt. 3, Sayı. 2

Journal of Tour Guiding (JOTOG) \& Year. 2020, Volume. 3, Issue. 2

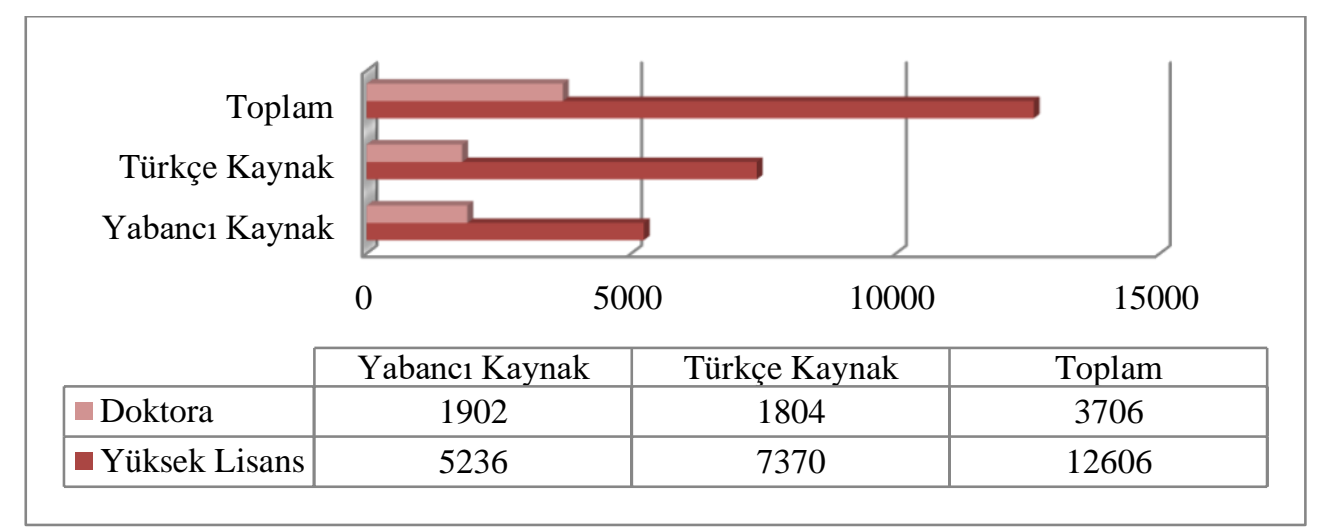

Şekil 13: Lisansüstü Tezlerin Türkçe ve Yabancı Kaynak Sayısına Göre Dağılımı

Yabanc1 kaynak kullanım oranı incelendiğinde, doktora tezlerinde kullanılan yabancı kaynak sayısının daha fazla olduğu dikkat çekmektedir. Yüksek lisans tezlerinde ise Türkçe kaynaklara daha fazla yer verildiği bulgular arasındadır. Lisansüstü eğitim, lisans derecesini tamamlamış öğrencinin ilgi gösterdiği bilim dalında yüksek lisans veya doktora öğrenimi yaparak öğrenciye uzmanlaşma imkânı veren, üst düzey eğitim programları (Beşel, 2017: 28) olarak değerlendirildiğinde, lisansüstü eğitimin ilk basamağı olan yüksek lisans tezlerinde Türkçe kaynaklara daha fazla yer verilirken, daha ileri düzeyde bir eğitim seviyesi olan doktora tezlerinde yabancı kaynaklara daha sık başvurulduğu sonucuna ulaşılmaktadır. Bu kapsamda daha ileri araştırmalar gerektiren doktora tezlerinin artması ve farklı kaynakların kullanımı alan ile ilgili bilgi birikimine, alanın zenginleşmesine ve araştırmacılara kolaylık sağlayacaktır.

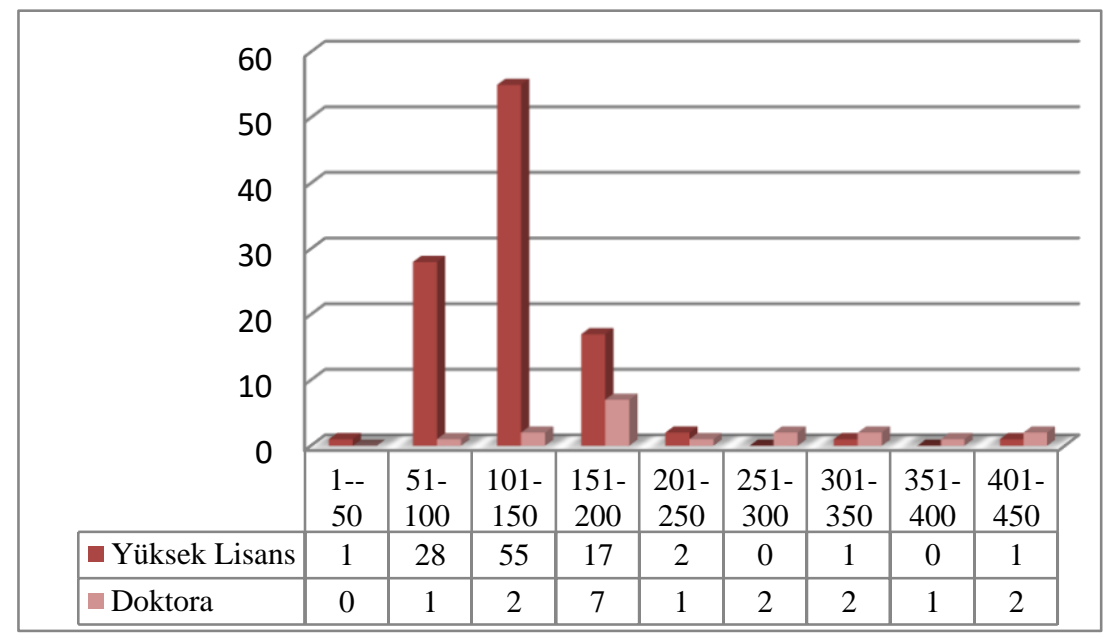

Şekil 14: Lisansüstü Tezlerin Sayfa Sayısına Göre Dağılımı

Şekil 14'te lisansüstü tezlerin sayfa sayısına göre dağılımı yer almaktadır. Tabloya göre analiz edilen yüksek lisans tezlerinin en fazla 101-150 sayfa aralığında, doktora tezlerinin ise 151200 sayfa aralığında hazırlanmış olduğu sonucuna ulaşılmaktadır. 51-100 arasındaki sayfa aralığında toplamda 29 tez, 151-200 sayfa aralığında ise 24 tezin hazırlanmış olduğu ulaşılan sonuçlar arasındadır. 401-450 sayfa aralı̆̆ında ise bir yüksek lisans tezi bulunurken, iki adet doktora tezi bulunmaktadir. 


\section{IIIIII}

Turist Rehberliği Dergisi (TURED) \& Y1l. 2020, Cilt. 3, Sayı. 2

Journal of Tour Guiding (JOTOG) \& Year. 2020, Volume. 3, Issue. 2

Lisansüstü tezlerin sayfa ortalamaları Şekil 15'te gösterilmektedir. Yapılan analizler sonucunda doktora tezlerinin sayfa ortalamas 214 bulunurken yüksek lisans tezlerinin ortalamas1 120 olarak belirlenmiş̧ir. Doktora tezlerinin gerek daha ileri düzeyde araştırma gerektirmesi gerekse doktora dönemi için belirlenen yasal sürenin daha uzun olduğu düşünüldüğünde bulgunun olağan olduğu ifade edilmelidir.

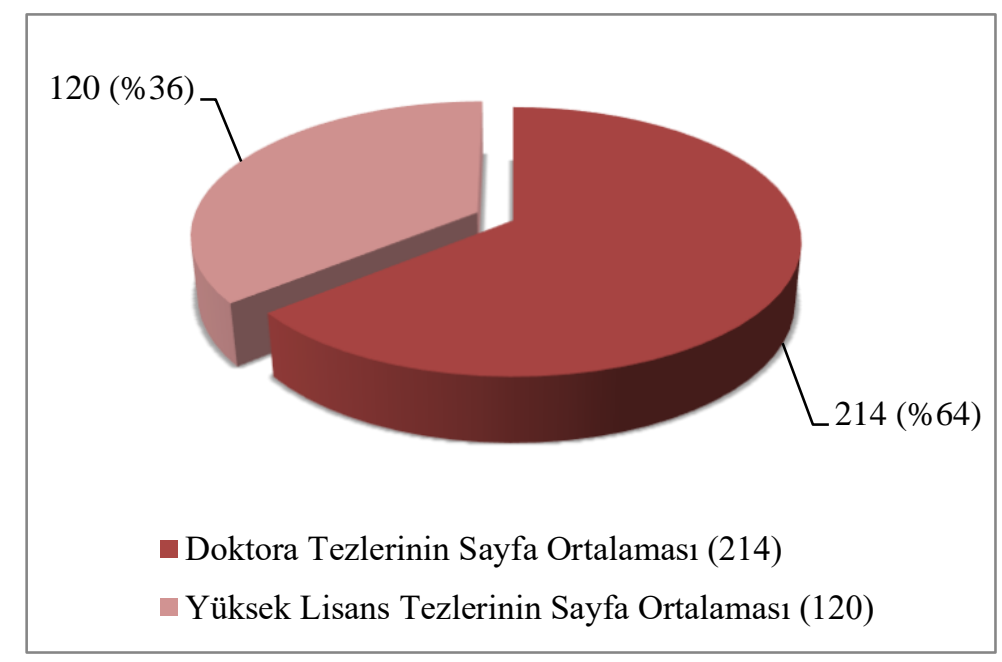

Şekil 15: Lisansüstü Tezlerin Sayfa Ortalamasına Göre Dağılımı

Turizm rehberliği alanı ile ilgili hazırlanan lisansüstü tezlerde en sık işlenen konuların dağılımını belirlemek amacıyla yapılan analizlerin sonucu Şekil 16'da gösterilmektedir. Yüksek lisans tezlerinde en sık işlenen konu \%12,3 oranında turist rehberlerinin rolleri ve fonksiyonları üzerine olurken, bu oran doktora tezlerinde \% 17,6 oranla turist rehberlerinin mesleki yeterlilikleri ve performansları üzerine hazırlanmıştır.

Ayrıca turist rehberliği eğitimi, mesleki sorunları, turistlerin tatil deneyimlerinde rehberlerin etkisi, performansları ve duygusal emek gibi konular da yüksek lisans tezlerinde en çok konu edinilen kavramlardır. Doktora tezlerinde ise rehberlik eğitimi, rehberlerin mesleki sorunları, turist deneyiminde rehberlerin rolü gibi konular seçilmiştir. Bu konular, Zengin ve Atasoy (2020)'un çalışmasında turizm rehberliği, hizmet kalitesi ve turist memnuniyeti ve turizm rehberliği ve kişisel gelişim olarak belirlenmiştir. Kaygalak ve Kırlar (2019) ise incelemiş oldukları turist rehberliği ile ilgili makalelerde en fazla işlenen konunun turist rehberlerinin rolü, performansı olduğu sonuçlarına ulaşmışlardır. Anahtar kelimeler bölümünde en sık tekrar eden kelimeler analiz edildiğinde turist, turist rehberi, eğitim, mesleki kelimelerinin konularla ilgili olmasından kaynaklı olarak beklenen bir sonuçtur. Bunlara ek olarak turizm dışındaki alanlarda hazırlanan tezlerde ise turist rehberliğinde hikâye anlatımı, vergi hukuku açısından rehberlik mesleğinin değerlendirilmesi, gezi edebiyatı gibi konularda yazılmış tezlerin olduğu da sonuçlar arasında yer almaktadır. İleri düzey eğitim gerektiren lisansüstü tezlerde konuların çeşitlenmesi ve derinlemesine incelenmesi ilgili alanın gelişimi açısından önemlidir. 
Turist Rehberliği Dergisi (TURED) \& Y1l. 2020, Cilt. 3, Sayı. 2

Journal of Tour Guiding (JOTOG) \& Year. 2020, Volume. 3, Issue. 2

\section{Doktora $\quad$ Yüksek Lisans}

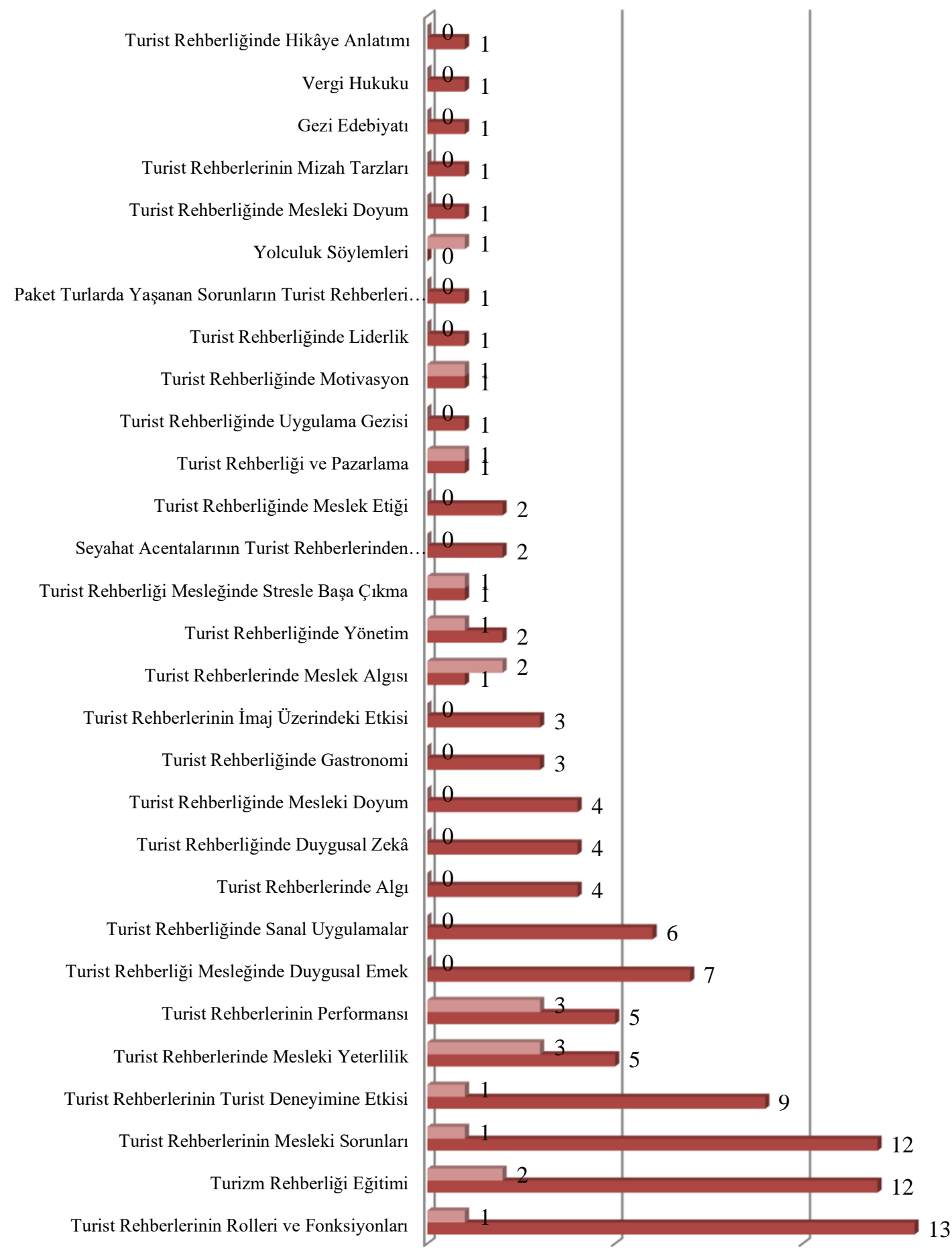

Şekil 16: Tezlerin Konularına Göre Dağılımı 


\section{IIIIII)}

Turist Rehberliği Dergisi (TURED) \& Y1l. 2020, Cilt. 3, Sayı. 2

Journal of Tour Guiding (JOTOG) \& Year. 2020, Volume. 3, Issue. 2

Şekil 17'de lisansüstü tezlerin anahtar kelimelerinde en s1k tekrar eden kelimelerin s1klık derecesi gösterilmektedir. Bu kelimelerden en sık tekrar eden kelimeler analize dâhil edilmiş olup sekizden az tekrarlanan kelimelere yer verilmemiştir. Doktora ve yüksek lisans tezlerinde yer alan anahtar kelimeler ayrı ayrı ele alınarak analiz edilmiştir.

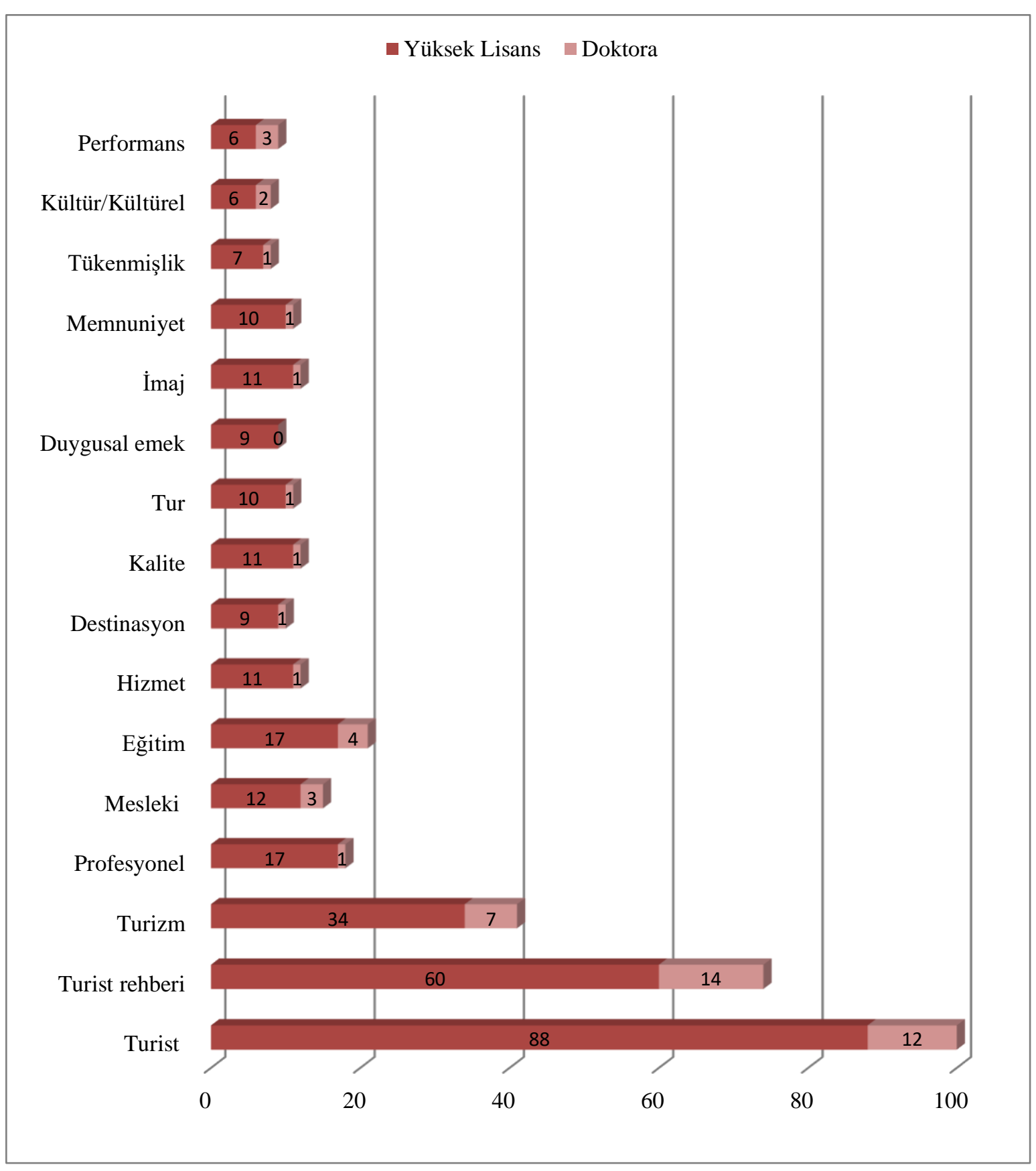

Şekil 17: Lisansüstü Tezlerin Anahtar Kelimelerinde En S1k Tekrar Eden Kelimelerin Dağılımı

Bu kapsamda incelendiğinde, "turist” sözcüğü yüksek lisans tezlerinde 88 kez tekrarlanırken bu sayı doktora tezlerinde 12 olarak görülmektedir. "Turist rehberi” sözcüğü doktora tezlerinde en sık tekrar eden kelime iken yüksek lisans tezlerinde 60 kez tekrarlanmıştır. 


\section{Sonuç ve Öneriler}

Bu araştırma ile 1989 yılından 2019 yılına kadar Yükseköğretim Kurulu Ulusal Tez Merkezi veri tabanında yayınlanan turist rehberliği alanı ile ilgili hazırlanmış, erişime açık lisansüstü tezler farklı parametreler çerçevesinde (yılı, türü, üniversitesi, enstitüsü, ana bilim dalı, danışman unvanı, örneklem alanı, araştırma türü, araştırma deseni, örneklem sayısı, uygulama kitlesi, veri toplama aracı, Türkçe ve yabancı kaynak sayısı, toplam sayfa sayısı, konusu ve anahtar kelimelerinde en sık tekrar eden kelimeler) değerlendirilerek son 30 yll gibi bir zaman diliminde ilgili akademik çalışmaların bütünsel bir yaklaşım ile fotoğrafı çekilmeye çalışılmıştır. Bu kapsamda yayınlanan ve erişime açık olan 123 lisansüstü tezin değerlendirilmesine bağlı olarak yapılmış bir çalışmanın ileride bu konuda çalışma yapacak olan başta lisansüstü öğrenciler olmak üzere akademik çevrelere yol gösterici niteliği ile katkılar oluşturacağı düşünülmektedir. Bu düşünce çerçevesinde akademik bir sahanın gelişiminde o saha ile ilgili lisansüstü tezlerin lokomotif olacağı varsayımı ile ilgili alan hakkında hazırlanan makale, bildiri gibi akademik çalışmaların zenginliği ve çeşitliliğine de doğrudan veya dolaylı olarak katkı sağlayacağı söylenebilir.

Araştırma bulgularına dayanarak, henüz gelişmekte olan turizm rehberliği akademik alanı ile ilgili yapılan lisansüstü tezlerin her yıl düzenli bir şekilde artış gösteren geçmişe sahip olmasa da özellikle 2015 yılı itibariyle yayınlanan tez sayısında istikrarlı bir artışın olduğu anlaşılmaktadır. Ayrıca gerek farklı yöntemlerin son zamanlarda kullanımının bu alanda yaygınlaşması gerekse farklı alanlarda turizm rehberliği üzerine çalışmalar yapılması, alanın gelişimi ve çok boyutlu olarak farklı alanlarda yaygın etki oluşturması ve kaynakların çeşitlenmesi açısından önemlidir. Turist rehberliğinde hikâye anlatımı, vergi hukuku açısından rehberlik mesleğinin değerlendirilmesi, gezi edebiyatı gibi konularda rehberlik alanı ile ilgili tezlerin bulunması ise konu çeşitliliğini artırarak gelecek çalışmalara yol gösterici nitelikte olarak değerlendirilebilmektedir. Turizm rehberliği alanının bu çalışmanın yayına hazırlandığı zaman zarfında henüz bağımsız bir doktora programının olmamasına karşın doktora düzeyinde yapılmış olan çalışmaların bulunması da alanın başta turizm genel alanı olmak üzere diğer akademik çalışma alanları açısından da dikkat çekici ve destek gören önemli bir düzeyde olduğu ve zamanla bu çalışmaların artmasının akademik çevrelere yol gösterici niteliği ile alana daha da katkı sağlayacağının bir göstergesi olarak değerlendirilebilir.

Çalışmada turist rehberliği ile ilgili akademik çalışma alanına bütünsel bakış ile genel manada çalışlan konular ve kullanılan yöntemlerin bilinmesi açısından turist rehberliği alanında araştırma yapacak olanlara konu seçimlerinde, veri toplama yöntemlerinde, örneklem seçimlerinde ve diğer benzeri açılardan mevcut çalışmanın yol gösterici nitelikte olduğu söylenebilir. Literatürde sadece lisansüstü tezleri detaylı bir şekilde inceleyen farklı bir çalışmanın bulunmaması da bu ve benzer çalışmaların önemine işaret etmektedir. Çalışmada sadece YÖKTEZ'de bulunan tezlerin değerlendirilmesi ve erişime kapalı olan tezlerin araştırmaya dâhil edilmemesi araştırmanın sınırlılı̆̆ını oluşturmaktadır. Bu kapsamda, ileride yapılacak çalışmalarda (a) erişime açılacak tezlerin de araştırmaya dâhil edilmesi, (b) uluslararası hazırlanan tezlerin de daha geniş parametreler dikkate alınarak hazırlanması ve (c) farklı akademik çalışmalarla karşılaştırma yapılması önerilmektedir.

\section{Kaynakça}

Al, U. \& Coştur, R. (2007). Türk Psikoloji Dergisi'nin Bibliyometrik Profili. Türk Kütüphaneciliği, 21 (2), 142-163.

Alkan, G. (2014). Türkiye'de Muhasebe Alanında Yapılan Lisansüstü Tez Çalışmaları Üzerine Bir Araştırma (1984-2012). Muhasebe ve Finansman Dergisi, (61), 41-52.

Alımanoğlu, Ç. \& Ayazlar, G. (2017). Türkiye'de Kırsal Turizm Konulu Lisansüstü Tez Çalışmaları Üzerine Bibliyometrik Bir İnceleme (2003-2016). International Rural Tourism and Development Journal (IRTAD), 1 (1), 6-12. 
Turist Rehberliği Dergisi (TURED) \& Y11. 2020, Cilt. 3, Sayı. 2

Journal of Tour Guiding (JOTOG) \& Year. 2020, Volume. 3, Issue. 2

Ap, J. \& Wong, K. F. (2001). Case Study on Tour Guiding: Professionalism, Issues and Problems. Tourism Management, 22 (5), 551-563.

Arıkan Saltık, I. \& Alimanoğlu, Ç. (2018). Turizmde Örgütsel Davranış Çalışmaları: Adım Üniversiteleri'nde Tamamlanan Lisanüstü Tezler Üzerine Bibliyometrik Bir Araştırma, İçinde International Conference On Applied Economics And Finance \& Extended Social Sciences, $393-$ 405, Aydın, Türkiye, 2018.

Arıkan Saltık, I. (2020). Turist Rehberliği Konulu Ulusal Lisansüstü Tezlerin Bibliyometrik Profili (1989-2018). ÇAKÜ Sosyal Bilimler Enstitüsü Dergisi/ Journal of Institute of Social Sciences, 11 (1), 45-69.

Armutlu, C. \& Arı, G. S. (2010). Yönetim Modalarının Yüksek Lisans ve Doktora Tezlerine Yansımaları: Bibliyometrik bir Analiz. METU Studies in Development, 37 (1), 1-23.

Ayaz, N. \& Türkmen, B. M. (2018). Yöresel Yiyecekleri Konu Alan Lisansüstü Tezlerin Bibliyometrik Analizi. Gastroia: Journal of Gastronomy and Travel Research, 2 (1), 22-38.

Aydın, B. (2017). Yükseköğretim Kurulu Tez Merkezinde (YÖKTEZ) Yiyecek İçecek İşletmeciliği Alanında Kayıtlı Bulunan Tezlerin Bibliyometrik Analizi. Disiplinlerarası Akademik Turizm Dergisi, 2 (1), 23-38.

Beşel, F. (2017). Türkiye'de Maliye Alanında Yapılmış Lisansüstü Tezlerin Bibliyometrik Analizi (2003-2017). International Journal of Public Finance, 2 (1), 27-62.

Bozok, D., Kılıç, S. N. \& Özdemir, S. S. (2017), Bibliometric Analysis of Rural Tourism on Tourism Literature. Journal of Human Sciences, 14 (1), 187-202.

Cohen, E. (1985). The Tourist Guide: The Origins, Structure and Dynamics of a Role. Annals of Tourism Research, 12 (1), 378-398.

Conner, C. J. \& Bohan, C. H. (2014). The Second World War's Impact on the Progressive Educational Movement: Assessing its Role. The Journal of Social Studies Research, 38 (2), 91102.

Çapar, G., Toksöz, D. \& Dönmez, B. (2018). Turizm Rehberliği Alanında Yapılan Akademik Çalışmaların İncelenmesi. Turist Rehberliği Dergisi (TURED), 1 (2), 57-73.

Dahles, H. (2002). The Politics of Tour Guiding Image Management in Indonesia. Annals of Tourism Research, 29 (3), 783-800.

Decrop, A. (1999). Triangulation in Qualitative Tourism Research. Tourism Management, 20 (1), 157-161.

Demirbulat, Ö. G. \& Dinç, N. T. (2017). Sürdürülebilir Turizm Konulu Lisansüstü Tezlerin Bibliyometrik Profili. Seyahat ve Otel Isşletmeciliği Dergisi, 14 (2), 20-30.

Diodato, V. P. (1994). Dictionary of Bibliometrics. The Hawthorne Press: USA.

Garfield, E. (1979). Is Citation Analysis a Legitimate Evaluation Tool?. Scientometrics, 1, (4), 359375.

Gökkaya, S., Acar, A. \& Yıldırım, M. (2017). Ekoturizm Konusunun Lisansüstü Tezlerdeki Bibliyometrik Profili. Karabük Üniversitesi Sosyal Bilimler Enstitüsü Dergisi, 3, 122-130.

Grönroos, C. (1978). A Service-orientated Approach to Marketing of Services. European Journal of Marketing, 12 (8), 588-601.

Güçlü Nergiz, H. (2014). Türkiye'de Lisansüstü Turizm Tezlerinin Bibliyometrik Profili (19902013), İçinde VII. Lisansüstü Turizm Öğrencileri Araştırma Kongresi, 212-221, Aydın, Türkiye, 04-05 Nisan 2014.

Hall, C. M. (2011). Publish or Perish? Bibliometric Analysis, Journal Ranking and the Assesment of Research Quality in Tourism. Tourism Management, 32 (1), 16-27.

İçöz, O. \& Başarır, A. (1996). Seyahat ve Turizm Araştırmalarında Anket Tekniğinin Kullanımı. Anatolia: Turizm Araştırmaları Dergisi, 7 (1), 14-23.

İnceoğlu Ç. (2014) Türkiye'de Sinemayı Konu Alan Doktora Tezleri Üzerine Bibliyometrik Bir Çözümleme. Galatasaray Üniversitesi İletişim Dergisi, 21, 31-50. 
Turist Rehberliği Dergisi (TURED) \& Y11. 2020, Cilt. 3, Sayı. 2

Journal of Tour Guiding (JOTOG) \& Year. 2020, Volume. 3, Issue. 2

Karagöz, D. \& Kozak, N. (2014). Anatolia Turizm Araştırmaları Dergisi'nin Bibliyometrik Analizi: Araştırma Konuları ve Kurumlar Arası İş Birliğinin Sosyal Ağ Analizi ile İncelenmesi. Türk Kütüphaneciliği, 28 (1), 47-61.

Karaman, S. \& Bakırc1, F. (2010). Türkiye'de Lisansüstü Eğitim: Sorunlar ve Çözüm Önerileri. Sosyal Bilimler Araştırmaları Dergisi, 2, 94-114.

Kaygalak, Ç. \& Kırlar, C. B. (2019). Turizm Rehberliği Alanında Yapılan Makalelerin Bibliyometrik Analizi. Uluslararası Güncel Turizm Araştırmaları Dergisi, 3 (2), 213-223.

Koseoglu, M. A., Sehitoglu, Y. \& Craft, J. (2015). Academic Foundations of Hospitality Management Research with an Emerging Country Focus: A Citation and Co-Citation Analysis. International Journal of Hospitality Management, 45, 130-144.

Koseoglu, M. A., Rahimi, R., Okumus, F. \& Liu, J. (2016). Bibliometric Studies in Tourism. Annals of Tourism Research, 61, 180-198.

Küçükoğlu, A. \& Ozan, C. (2013). Sınıf Öğretmenliği Alanındaki Lisansüstü Tezlere Yönelik Bir İçerik Analizi. Uluslararast Avrasya Sosyal Bilimler Dergisi, 4 (12): 27-47.

Lee, S. H. (2015). A Bibliometric Analysis of the Field of Records Management: A Case Study of Records Management Journal, 1989-2013. Doctoral Dissertation, Canada: University of Toronto.

Nguyen, H. L. (2015). The Impacts of Tour Guide Performance on Foreign Tourist Satisfaction and Destination Loyalty in Vietnam. Doctoral Dissertation, Australia: University of Western Sydney.

Özel, Ç. H. \& Kozak, N. (2012), Turizm Pazarlaması Alanının Bibliyometrik Profili (2000- 2010) ve Bir Atıf Analizi Çalışması. Türk Kütüphaneciliği, 26 (4), 715-733.

Özsoy, A. \& Çokal, Z. (2018). Türkiye'de Turist Rehberliği Alanında Yayımlanmış Lisansüstü Tezlerin Bibliyometrik Analizi (1989-2018), İçinde 2. International EMI Entrepreneurship \& Social Sciences Congress, Nevşehir, Türkiye, 09-11 Kasım 2018.

Pritchard, A. (1969). Statistical Bibliography or Bibliometrics. Journal of Documentation, 25 (4), 348-349.

Sünnetçioğlu, A., Yalçınkaya, P., Olcay, M. \& Okan, Ş. (2017). Turizm Alanında Yazılmış Olan Gastronomiye İlişkin Tezlerin Bibliyometrik Profili. Journal of Tourism and Gastronomy Studies, 5 (2), 345-354.

Şahin, S. \& Acun, A. (2015a). Turist Rehberliği Alanının Bibliyometrik Profili (Makaleler ve Lisansüstü Tezler), İçinde 16. Ulusal Turizm Kongresi, 12-15. Detay Yayıncılık, Ankara, Türkiye, 2015.

Şahin, S. \& Acun, A. (2015b). Turist Rehberliği Alanının Bibliyometrik Profili (Ulusal Turizm Kongreleri Bildirileri). Balikesir University Journal of Social Sciences Institute, 18 (34), 213234.

Tayfun, A., Küçükergin, F. N., Aysen, E., Eren, A. \& Özekici, Y. K. (2016). Turizm Alanında Yazılan Lisansüstü Tezlere Yönelik Bibliyometrik Bir Analiz. Gazi Üniversitesi Turizm Fakültesi Dergisi, (1), 50-69.

Tayfun, A., Ülker, M., Gökçe, Y., Tengilimoğlu, E., Sürücü, Ç. \& Durmaz, M., (2018). Turizm Alanında Yiyecek ve İçecek ile İlgili Lisansüstü Tezlerin Bibliyometrik Analizi. Journal of Tourism and Gastronomy Studies, 6, 523-547.

Temizkan, P., Çiçek, D. ve Özdemir, C. (2015), Bibliometric Profile of Articles Published on Health Tourism. Journal of Human Sciences, 12 (2), 394-415.

Ülker, P., Örnek, N. \& Çalhan, H. Turizm Dergilerinde Yayınlanan İnovasyon Başlıklı Makalelerin Bibliyometrik Profili. Seyahat ve Otel İşletmeciliği Dergisi, 17 (1), 103-123.

Üzümcü, T. P. (2019). Turizm Eğitimi Alanına Yönelik Bibliyometrik Bir Çalışma. Türk Turizm Araştırmaları Dergisi, 3 (4), 1433-1449.

Wallin, J. A. (2005). Bibliometric Methods: Pitfalls and Possibilities. Basic \& Clinical Pharmacology \& Toxicology, 97 (5), 261-275.

Yıldırım, A. \& Şimşek, H. (2018). Sosyal Bilimlerde Nitel Araştırma Yöntemleri (11. Baskı). Ankara: Seçkin Yayıncılık. 
Turist Rehberliği Dergisi (TURED) \& Y1l. 2020, Cilt. 3, Sayı. 2

Journal of Tour Guiding (JOTOG) \& Year. 2020, Volume. 3, Issue. 2

YÖK Atlas (2019). Yükseköğretim Program Atlası, https://yokatlas.yok.gov.tr/ (Erişim Tarihi: 25.07.2019).

Yükseköğretim Kanunu (1981). https://www.mevzuat.gov.tr/MevzuatMetin/1.5.2547.pdf (Erişim tarihi: 05.11.2020)

Zengin, B. \& Atasoy, B. (2020). Turizm Rehberliği Alanındaki Lisansüstü Tezlerin Bibliyometrik Çerçevesi. Alanya Akademik Bakış Dergisi, 4 (3), 975-992.

Zillinger, M., Jonasson, M. \& Adolfsson, P. (2012). Guided Tours and Tourism. Scandinavian Journal of Hospitality and Tourism, 12 (1), 1-7.

\section{ETIKK ve BILLIMSEL ILKELER SORUMLULUK BEYANI}

Bu çalıșmanın tüm hazırlanma süreçlerinde (veri toplama, yazım vb.), tüm etik kurallara ve bilimsel atıf gösterme ilkelerine riayet edildiğini, herhangi bir hataya mahal vermemek için yayımdan önce makalenin bir intihal programı aracılığıyla da kontrol edildiğini yazarlar beyan eder. Ayrıca yazarlar aşağıda sıralanan hususları kabul etmiştir:

1. Çalıșmada yer alan ve kullanılan tüm kaynaklara, bilimsel araștırma yöntemleri ve etik ilkeler doğrultusunda atıf yapılmıștır.

2. Çalışmada tüm yazarların akademik-bilimsel olarak doğrudan ve ortak katkısı vardır.

3. Bu çalıșma, yazarların özgün bir çalıșmasıdır.

4. Bütün yazarlar dergiye gönderilen makaleyi görmüş ve sonuçlarını onaylamıştır.

5. Çalışmada kullanılan denek/deneklere ilişkin herhangi bir etik ihlal yapılmamış, kullanılan tüm veri toplama yöntemlerinde bilimsel etik ilkelere göre hareket edilmiștir.

6. Çalışma daha önceden bilimsel bir toplantıda sunulan özet veya bu çalışmanın daha kısa hali ise, makalede bu durum belirtilmiştir.

7. Calıșmada, hiçbir suç unsuru veya kanuna aykırı ifade bulunmamakla birlikte, araștırma yapılırken kanuna aykırı herhangi bir yöntem kullanılmamış olup, çalışma ile ilgili tüm yasal izinler alınmış ve etik kurallara uygun hareket edilmiştir.

Aksi bir durumun tespiti halinde Turist Rehberliği Dergisi’nin hiçbir sorumluluğu olmayıp, tüm sorumluluk makale yazarlarına aittir.

Tarih $\quad: 12 / 11 / 2020$

Sorumlu Yazar : Nazlı ÖRNEK 